\title{
POLÍTICA LINGUÍSTICA NA OCEANIA: NAS FRONTEIRAS DA COLONIZAÇÃO E DA GLOBALIZAÇÃO
}

\author{
Diego BARBOSA DA SILVA*
}

- RESUMO: Neste artigo, apresentamos um panorama das políticas linguísticas dos países e territórios da Oceania após análise de legislações, planos e programas de governo. Com $22,9 \%$ de todas as línguas do mundo, a grande maioria falada por poucas pessoas e ameaçada de desaparecimento, esse continente sofreu uma intensa colonização linguística marcada pela instrumentalização das línguas indígenas por missionários religiosos e pela posterior imposição da língua europeia como única permitida durante o imperialismo europeu e o americano. Tal cenário ampliou a complexa situação linguística da Oceania e impôs aos países da região muitos desafios em torno de qual língua adotar após a independência frente a muitos problemas locais, fazendo com que os oceânicos buscassem diversas soluções políticas e se tornassem povos de fronteiras, fronteiras de línguas, fronteiras de sentidos, fronteiras de memórias entre as línguas colonizadoras, as autóctones e as línguas imigrantes.

- PALAVRAS-CHAVE: Política linguística. Oceania. Colonização linguística. Bilinguismo. Línguas em contato.

\section{Introdução}

Último continente a ser visitado pelos europeus, a Oceania, ainda hoje é um espaço geopolítico pouco conhecido no Ocidente. Formado atualmente por 14 Estados independentes, além de 17 territórios habitados, com maior ou menor autonomia político-administrativa - da França, do Reino Unido, do Chile, da Indonésia, dos Estados Unidos e das próprias Austrália e Nova Zelândia —, o continente oceânico tem $9.088 .818 \mathrm{~km}^{2}$, o que o faz um pouco maior que o Brasil. É habitado, porém, por apenas 46,9 milhões de pessoas (UNFPA, 2019), isto é, uma população um pouco superior a da Argentina. ${ }^{1}$ E apesar de não muito conhecido, o continente é muitas vezes lembrado pelo seu maior país, a Austrália, que corresponde a $84,6 \%$ do território e concentra $52 \%$ de

\footnotetext{
Arquivo Nacional do Brasil (AN), Rio de Janeiro - RJ - Brasil. vsjd@uol.com.br. ORCID: 0000-0002-0838-1106.

1 Como demonstram Kirch (2000) e Cochrane e Hunt (2018), delimitar as fronteiras do continente oceânico é algo complexo e varia de acordo com critérios arqueológicos, geológicos, antropológicos, linguísticos e (geo)políticos, podendo incluir algumas ilhas japonesas e até mesmo o Timor-Leste ou excluir o estado americano do Havaí, Rapa Nui (Ilha de Páscoa) ou a parte ocidental da Ilha da Nova Guiné.
} 
sua população. Tais números muitas vezes fazem com que o continente seja apresentado como um sinônimo de seu maior país, como se não houvesse outras 13 nações que se agrupam em três grandes regiões geográficas históricas como a Micronésia, a Melanésia e a Polinésia. ${ }^{2}$ Contudo, sob o aspecto linguístico, a Austrália corresponde atualmente apenas a cerca de 13,5\% das línguas do continente, de um total de 1630 línguas (ETHNOLOGUE, 2017). ${ }^{3}$ Isso significa que esses 13 países — Fiji, Ilhas Marshall, Ilhas Salomão, Kiribati, Micronésia, Nauru, Nova Zelândia, Palau, Papua-Nova Guiné, Samoa, Tonga, Tuvalu e Vanuatu - e 17 territórios - Guam, Havaí, Ilha Christmas, Ilha Norfolk, Ilhas Cocos (Keeling), Ilhas Cook, Ilhas Marianas do Norte, Ilhas Pitcairn, Niue, Nova Caledônia, Papua, Papua Ocidental, Polinésia Francesa, Rapa Nui (Ilha de Páscoa), Samoa Americana, Tokelau e Wallis e Futuna — apresentam aproximadamente 1400 línguas. Isso indica que 22,9\% de todas as línguas do mundo são originárias dos países e territórios do continente ou faladas neles, uma região que concentra apenas 0,5\% da população mundial (UNFPA, 2019), tornando-se, assim, de acordo com Lynch (1998), linguisticamente a região mais complexa do mundo.

Todas essas línguas podem ser reunidas em seis grandes grupos: a) línguas austronésias; b) línguas trans-neo-guineanas; c) línguas indo-europeias; d) línguas australianas; e) línguas de sinais e f) línguas crioulas, que remetem a sua maioria às formas de povoamento humano do continente há milhares de anos (LYNCH, 1998; PAWLEY, 2013). De acordo com Ethnologue (2017), a família das línguas austronésias engloba aproximadamente 1256 línguas em um vasto território que inclui desde a ilha de Madagascar, na África, a Indonésia e Filipinas na Ásia, até parte da ilha Nova Guiné, a Micronésia, a Melanésia e a Polinésia na Oceania, incluindo a Nova Zelândia e o Havaí.

A família das línguas trans-neo-guineanas é composta por cerca de 483 línguas e se estende pela Indonésia, Timor-Leste, Papua-Nova Guiné e Ilhas Salomão. Já a família das línguas indo-europeias engloba aproximadamente 449 línguas. Essas línguas chegaram ao continente por meio da colonização linguística e atualmente estão presentes

\footnotetext{
Tal divisão do continente nessas regiões foi feita pelo explorador francês Dumont d'Urville baseada em critérios racistas e evolucionistas do século XIX em que os polinésios seriam os mais avançados em relação a micronésios e esses em relação aos melanésios por se organizarem em torno de chefias indígenas (COCHRANE; HUNT, 2018). Mas recentemente, levando em consideração critérios arqueológicos, antropológicos e linguísticos, Green e Pauley (apud COCHRANE; HUNT, 2018) dividiram a Oceania em duas regiões. A Oceania Próxima formada pela Nova Guiné, pelas ilhas Bismarck, Austrália e grande parte das Ilhas Salomão e a Oceania Remota formada pelas demais ilhas do continente. Enquanto a colonização da Oceania Remota ocorreu há cerca de três mil anos, a Oceania Próxima tem resquícios populacionais que datam de 50 mil anos.

3 Como sabemos, delimitar fronteiras linguísticas e culturais, assim como as de um continente, é algo bastante complexo, e diríamos inclusive político-ideológico, e já foi tratado por nós em outra oportunidade (BARBOSA DA SILVA, 2018). Desse modo, precisar quantas línguas são faladas no mundo ou na Oceania não é uma tarefa fácil e muitas vezes também controversa. Mühlhäusler (1996) menciona aproximadamente 1470 línguas; Lynch (1998), 1400; Kirch (2000), 1200; Lal e Fortune (2000), 1000; Pawley (2013), 1300. Decidimos tomar como referência os dados do Ethnologue pois, embora em sua história esteja o antigo Summer Institute of Linguistics, com finalidades religiosas, inclusive na Oceania, atualmente, seu banco de dados compila diversas pesquisas de linguistas a respeito das línguas do mundo, permitindo-nos, assim, ter um panorama mais geral sobre elas. Cabe lembrar que independentemente do número exato de línguas faladas no continente, não nos restam dúvidas de que, como em outras regiões colonizadas do planeta, muitas mais eram faladas na Oceania antes da colonização europeia.
} 
em todos os países da região, com destaque para o inglês, e depois, o francês. Todas essas três famílias podem ser divididas em diversas famílias menores.

O quarto grupo é composto por cerca de 379 línguas da Austrália — metade já extinta - de diversas famílias linguísticas isoladas. O quinto grupo é formado por 142 línguas de sinais e está presente de forma dispersa pelo mundo. $\mathrm{Na}$ Oceania, destacamse a língua australiana de sinais e a língua neozelandesa de sinais. O último grupo é composto pelas línguas crioulas e pidgins, formadas a partir do contato de línguas, possuindo geralmente uma base linguística europeia. ${ }^{4}$

Atualmente, as línguas crioulas e pidgins se estendem pela América, África, Ásia e Oceania, sendo que na Oceania existem quinze dessas línguas. Os crioulos e pidgins de base inglesa do continente são: o crioulo pijin (Ilhas Salomão), o pidgin havaiano, o crioulo do Estreito de Torres (Austrália), o crioulo bislama (uma das línguas oficiais de Vanuatu), o crioulo de Queensland, o crioulo ngatik (Micronésia), o crioulo norfuk (Ilha Norfolk), o crioulo pitkern (Ilhas Pitcairn) e o crioulo tok pisin, que é falado como segunda língua por quatro milhões de papuásios. De base francesa tem-se o crioulo tayo (Nova Caledônia) e o crioulo neocaledônio (já extinto) e de base alemã, o crioulo unserdeutsch (Papua-Nova Guiné). De base austronésia/asiática têm-se o crioulo malaio-papuásio (Papua e Papua Ocidental), o crioulo malaio das Ilhas Cocos e o crioulo hiri motu (Papua-Nova Guiné) (HOLM, 2000; ETHNOLOGUE, 2017).

Se levarmos em consideração a grande quantidade de línguas em relação à população e em comparação com os demais continentes, a Oceania apresenta a menor proporção de falantes por língua do mundo. Tal proporção fica ainda mais surpreendente se analisarmos separadamente alguns países do continente, como Vanuatu, onde essa proporção alcança uma língua para cada 2,5 mil habitantes em média. ${ }^{5}$ Por conta disso e pela elevação do nível do mar causada pelas mudanças climáticas, ${ }^{6}$ que ameaça muitos países insulares, de acordo com a Unesco (2010), 319 línguas da Oceania - a maior parte dessas do grupo de línguas australianas - correm o risco de extinção nos próximos anos.

Além desses fatores ecológico e demográfico (ou demolinguístico), Hamel (2008) apresenta outros que contribuem para o desaparecimento ou o deslocamento das línguas: a) a assimetria de poder entre comunidades linguísticas em contato; b) a falta de lealdade linguística no interior das comunidades subalternas; c) a expansão das

\footnotetext{
Para a diferenciação entre línguas crioulas e pidgins, conferir Couto (1996) e Holm (2000).

Segundo Lynch (1998) basicamente, a Micronésia e a Polinésia têm uma língua por ilha ou grupo de ilhas. Já a Melanésia, onde está Vanuatu, apresenta muitas línguas por ilha, concentrando assim, uma das maiores diversidades linguísticas do mundo. Isso se justificaria, de acordo com Lynch (2017), por conta do tempo de ocupação humana da Melanésia em relação às demais áreas; pela separação geográfica natural (rios, montanhas, florestas) em regiões da Melanésia ao contrário do oceano que permitiu vasto contato entre ilhas e atóis da Micronésia e Polinésia e pela diferente estrutura social das regiões, enquanto sociedades polinésias se organizavam em chefias indígenas, nas sociedades melanésias não havia hierarquia definida.

${ }_{6}$ O aquecimento global causado pela emissão de gases poluentes ameaça diversas ilhas, atóis e arquipélagos da Oceania principalmente na Micronésia e na Polinésia, como em Tuvalu, Tokelau e Kiribati. Tuvalu, formado por nove atóis tem inclusive mantido uma postura bastante atuante nas Conferências Climáticas da ONU, condenando as emissões de gases dos países ricos (CORLEW, 2012; FRY; TARTE, 2016).
} 
línguas dominantes, nacionais e internacionais através do Estado (educação pública), a mídia e o comércio; d) a falta de reconhecimento e apoio externo (estatal) e e) a repressão às línguas minoritárias.

Frente a tal contexto, neste artigo, buscamos justamente fornecer um panorama da situação política das línguas dos países e territórios da Oceania, a partir de uma análise de suas legislações e políticas para que possamos refletir sobre os desafios que o colonialismo e a globalização impõem não só a esses países, mas a todo o mundo. Acreditamos que nossa visão a partir de uma área geográfica que, apesar de não ter muita tradição ou pesquisas sobre essa região, também foi colonizada e encontra-se também na periferia do sistema mundial, como o Brasil, pode contribuir para a reflexão em torno dessa temática.

Vale ressaltar que essa não é uma tarefa fácil devido à diversidade de povos, línguas e contextos históricos de cada país e território da Oceania. Todavia, nosso objetivo, pelo menos neste momento, não é aprofundar tais políticas de acordo com as especificidades de cada país, mas sim nos concentrar em apresentar um cenário das políticas linguísticas do continente a partir da colonização.

\section{Mapa 1 - Divisão da Oceania por regiões}

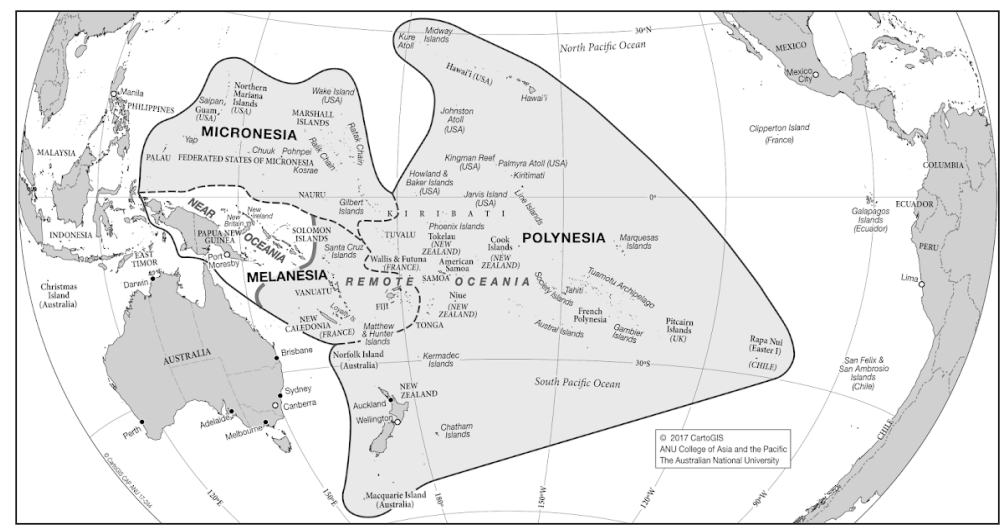

Fonte: Skirgård e Cartogis (2019). Distribuído sob licença Creative Commons BY-SA License.

\section{A colonização linguística na Oceania}

O primeiro europeu a chegar à Oceania foi o português, a serviço da Espanha, Fernão de Magalhães durante a primeira viagem europeia de circunavegação do planeta, aportando nas Ilhas Marianas, que ele batizou de Ilhas de Lázaro em 06 de março de 1521 (CAMPBELL, 2003). Após esse primeiro contato, outros europeus de diversos países visitaram o continente, como o espanhol Alvaro de Mendaña que aportou nas Ilhas Salomão e na Polinésia em 1567, o neerlandês Abel Tasman na Tasmânia, Nova Zelândia, Tonga e Fiji em 1642-1643, o inglês James Cook em três viagens entre 1768 
e 1779 quando visitou Austrália, Alasca, Havaí, Nova Zelândia e ilhas da Polinésia e o francês Louis Antonie de Bougainville entre 1766 e 1769 na Polinésia durante a primeira circunavegação francesa (CAMPBELL, 2003; QUANCHI; ROBSON, 2009). Mesmo com tantos registros de viagens europeias à região, até hoje prevalece no imaginário social como discurso dominante que o continente foi descoberto ${ }^{7}$ por James Cook, o primeiro europeu a chegar à Austrália em 1768 e reivindicá-la como possessão inglesa, ainda que tal fato seja questionado por Portugal. ${ }^{8}$

Cabe ressaltar que quando os europeus chegaram à Oceania, encontraram, assim como no Brasil, milhares de indivíduos divididos em centenas de etnias e culturas. Esses indivíduos se organizavam em chefias indígenas ou em outras sociedades não hierárquicas e, como dissemos, seus ancestrais teriam migrado para a Oceania pelas ilhas da Indonésia até a Nova Guiné há 50 mil anos e de lá e das Filipinas para as demais ilhas há cerca de três mil anos, desenvolvendo civilizações como, por exemplo, a cultura Lapita (1300-800 a.C.), na Melanésia; as cidades de Nan Madol (0-1700 d. C.) e de Leluh (500-1800 d.C.), na Micronésia; o Império de Tonga (950-1865 d.C.), e a mais conhecida no mundo, Rapa Nui/Ilha de Páscoa (1000-1400 d.C.) e seus moais, os dois últimos na Polinésia (KIRCH, 2000; CAMPBELL, 2015; COCHRANE; HUNT, 2018).

A história colonial europeia na Oceania pode ser dividida em duas fases bastante distintas como ocorreu na África e na Ásia. ${ }^{9}$ A primeira vai da chegada de Magalhães no século XVI até a segunda metade do século XIX e é a fase das expedições exploratórias e comerciais, relacionadas ao capitalismo comercial, quando a América passava por intenso colonialismo. A segunda fase vai do século XIX até a II Guerra Mundial e se insere no capitalismo industrial, marcada pelo imperialismo europeu, a anexação de territórios no continente e a formação de áreas de influência.

A colonização da Oceania não foi muito diferente daquela que os europeus aplicaram na América ou na África. Também houve forte violência na imposição da superioridade militar sobre os povos autóctones, deslocamentos forçados da população, ${ }^{10}$

Para refletir a respeito dos diversos sentidos possíveis sobre o contato entre europeus e povos indígenas por meio da colonização, sugerimos conferir Orlandi (2008) e Barbosa da Silva (2018) que demonstram mediante do aparato teórico-metodológico de Michel Pêcheux, as disputas ideológicas de sentido entre o discurso do descobrimento e o discurso da invasão.

8 Tal polêmica, em torno do discurso do descobrimento, também recai sobre o primeiro europeu a avistar a Austrália. Os portugueses defendem que foram dois compatriotas os primeiros a alcançar a Austrália: Cristóvão de Mendonça em 1522 e Gomes de Sequeira em 1525. Por ter sido o último continente habitado a ser "descoberto" pelos europeus foi chamado de Novíssimo Mundo. Inclusive, o nome Austrália é atribuído a outro português, Pedro de Queirós que chamou as atuais ilhas Vanuatu de Austrália do Espírito Santo, em relação a sua posição geográfica em 1605 (QUANCHI; ROBSON, 2009).

9 Mühlhäusler (1996), de forma mais detalhada, divide a história colonial da Oceania em quatro períodos: 1) de 1500 a 1750 - fase da exploração e comércio espanhóis; 2) de 1750 a 1830 - fase das descobertas científicas e antropológicas; 3) de 1830 a 1880 — fase da moderna exploração econômica e 4) de 1880 a 1975 — fase do contato colonial.

10 Segundo estimativas, entre 22 e 27 mil pessoas foram levadas forçosamente de Kiribati, Tuvalu, Vanuatu, Papua-Nova Guiné e Ilhas Salomão para Fiji entre 1864 e 1911, em uma prática que ficou conhecida como blackbirding. De 1863 a 1904, aproximadamente 62 mil pessoas foram levadas principalmente da Papua Nova Guiné, Vanuatu e Ilhas Salomão para Queensland, na Austrália. Entre 1862 e 1863 cerca de três mil pessoas - homens, mulheres e crianças — foram levadas de Niue, Rapa Nui, Tokelau e Tuvalu para o Peru e em 1879, 1.210 kitibatianos e vanuatuanos foram levados a 
grande declínio populacional, introdução de doenças desconhecidas, instituição da propriedade privada, até então desconhecida pelos nativos, e o envio de missionários católicos e protestantes para cristianizar os habitantes das ilhas, visto como sinônimo de desenvolvimento (DENOON, 1997; CAMPBELL, 2003). Essa primeira fase é marcada, de início, pelo avistamento de diversas ilhas pelos europeus, pelos primeiros contatos e pela troca de presentes com povos nativos na tentativa de formar alianças que auxiliassem e permitissem a exploração das ilhas (FISCHER, 2013; CHAPPELL, 2013a). Nesse primeiro período, as ilhas do Pacífico foram utilizadas para a extração de fruta pão, para a pesca de pepinos do mar, ao final do século XVIII para a extração de sândalo e para a caça de baleia; e ainda como parada para as travessias do Oceano Pacífico, já que a princípio não apresentou recursos minerais satisfatórios como na América Latina (LAL; FORTUNE, 2000) ${ }^{11}$.

A Austrália e a Nova Zelândia, no entanto, apresentam um capítulo à parte dentro dessa história colonial, com algumas peculiaridades que merecem destaque.

A Austrália foi alcançada por europeus tardiamente, em relação a muitas ilhas da Oceania, mas, ao contrário delas, foi ocupada imediatamente. Vinte anos após a chegada de James Cook, é fundada, em 1788, a cidade de Sidney, no sudeste do atual país, por William Bligh. Rapidamente, Sidney se tornou um importante entreposto comercial com indústria naval ao tempo em que crescia o comércio com o Havaí, os Estados Unidos e o Taiti (CAMPBELL, 2003).

Apesar de a Austrália ter apresentado também uma colonização de exploração com a formação de plantations em Queensland, no nordeste do país, utilizando mão de obra por deslocamento forçado da Melanésia, a colonização que prevaleceu foi a de povoamento como no Canadá e nos Estados Unidos. De início, o povoamento foi feito por pessoas que cometeram crimes no Reino Unido. Os condenados, após cumprirem pena na Austrália, recebiam uma pequena parcela de terra desabitada para cultivo, mas eram proibidos de retornar às Ilhas Britânicas. Tal política cessou apenas em 1968, quando o número de migrantes já era superior ao número de condenados (MACINTYRE, 2009). ${ }^{12}$

Samoa. Outros deslocamentos ainda foram feitos em direção à Nova Caledônia e ao Havaí. Todos esses deslocamentos tinham o mesmo objetivo: fornecer mão de obra barata para as plantations de açúcar, algodão e arroz e também para a mineração. Contudo, muitos morriam na travessia ou durante o trabalho nas plantations (SCARR, 1990; HORNE, 2007; GRAIG, 2011). Algumas áreas da Oceania também receberam imigrantes de outros continentes como indianos em Fiji e japoneses na Micronésia e no Havaí, muitos também para o trabalho nas plantations. Tal migração colaborou com a transformação da situação linguística dessas regiões.

11 Apenas no final do século XIX, portanto já na segunda fase colonial, que os europeus descobriram reservas minerais consideráveis de fosfato em Nauru, Kiribati, Palau e Polinésia Francesa; ouro e cobre na Nova Caledônia e Papua Nova Guiné, níquel também na Nova Caledônia e ouro em Fiji (DENOON, 1997). Algumas minas trouxeram sérias consequências ambientais como em Nauru, onde o centro da ilha encontra-se hoje devastado e inabitado. Outras minas continuam em plena produção. Atualmente a Nova Caledônia é um dos seis maiores produtores de níquel do mundo (USGS, 2011). A Austrália e a Nova Zelândia também fogem a essa regra por terem passado por ciclos do ouro já na metade do século XIX.

12 De acordo com estimativas, de 1788 a 1968, foram levados à Austrália aproximadamente 165 mil condenados (AUSTRALIA, 2008). 
Quanto à Nova Zelândia, a colonização inglesa iniciou-se no final do século XVIII, com as primeiras missões exploratórias do território. Lá os ingleses encontraram os maoris, que povoaram a Nova Zelândia por volta de 1200 d.C., vindos da Polinésia Oriental. Diferentemente da Austrália, a Nova Zelândia era habitada por apenas um povo, que vivia sobretudo nas áreas mais quentes ao norte da Ilha do Norte. Porém, como na Austrália, a opção colonial da Nova Zelândia se deu pelo povoamento, primeiro com entrepostos para a caça a baleias e depois por missionários e pecuaristas para a criação de ovelhas. Tal povoamento intensificou-se a partir de 1840, quando foi assinado o Tratado de Waitangi, entre o Reino Unido e líderes maoris, em uma espécie de anexação formal do arquipélago. Os anos posteriores foram marcados por conflitos entre colonos e maoris por conta da ocupação forçada de terras indígenas e pela instituição de um autogoverno a partir da Constituição de 1852 (KING, 2003).

Ao contrário dos demais países do continente, a Austrália e a Nova Zelândia conquistaram suas independências ainda que mantendo uma união com o Reino Unido relativamente cedo em 1901 e em 1907 respectivamente, enquanto os demais países estavam passando pela segunda fase de colonização aqui citada. Isso permitiu, inclusive, que esses dois países assumissem do Reino Unido o papel de potência colonizadora após a I Guerra Mundial em muitos países como Samoa, Papua-Nova Guiné e Nauru, permanecendo até hoje na Ilha Norfolk, nas Ilhas Cook e em Niue. ${ }^{13}$

Na metade do século XIX, a Revolução Industrial que se iniciou na Inglaterra um século antes, se espalhava pelos demais países europeus como França, Países Baixos, Bélgica e Estados alemães. O capitalismo, assim, entrava na sua fase imperialista. Para prosseguir na acumulação de capital, os Estados europeus na busca cada vez maior por mercados consumidores e matérias primas, construíram vastos impérios coloniais (HOBSBAWM, 2011). Um importante marco simbólico desse acontecimento foi a Conferência de Berlim (1884-1885), em que os europeus partilharam a África e ocuparam quase todas as terras do continente.

Como a África, a Oceania passou por um período de ocupações imperiais pelas potências europeias, que agiam, de acordo com Ferro (1996), de "forma preventiva", tomando posse de terras antes que o rival o fizesse, mas diferentemente do continente africano, a Oceania não foi partilhada por meio de um tratado específico ou ação deste gênero. Desse modo, em 1842, temendo perder mais espaço no Oceano Pacífico, após o Tratado de Waitangi, que incorporou a Nova Zelândia ao Reino Unido, a França anexou as Ilhas Marquesas na Polinésia, no primeiro ato calculado de imperialismo no continente (CAMPBELL, 2003). Por volta de 1850, a França também anexou as Novas Hébridas (Vanuatu) e a Nova Caledônia, na Melanésia. Temendo ataques de outras potências, chefes locais solicitaram que os britânicos assumissem a proteção de seus territórios em Tokelau, em 1877, e em Rotuma, em 1881 (GRAIG, 2011).

13 As Ilhas Cook e Niue têm um status diferente entre todos os territórios não independentes da Oceania. São Estados associados à Nova Zelândia, com total autonomia interna, porém dependentes em assuntos exteriores, embora atualmente tal regra venha sendo contrariada. 
Entre os anos de 1884 e 1886, a Alemanha e o Reino Unido dividiram a Nova Guiné e as Ilhas Salomão, bem como criaram áreas de influência alemã nas Ilhas Carolinas (Micronésia) e britânica nas Ilhas Gilbert (Kiribati) e nas Ilhas Ellice (Tuvalu). A Alemanha anexou ainda as Ilhas Marshall (1885) e Nauru (1888), após fazer alianças com os governos locais e impôs um tratado a Samoa (LAL; FORTUNE, 2000; McINTYRE, 2014). O Reino Unido, por sua vez, percebendo o vácuo de poder na região e que as alianças alemãs com os governos locais favoreceriam o avanço do país, decidiu ocupar definitivamente as ilhas Gilbert e Ellice em 1892 (CAMPBELL, 2003).

Os Estados Unidos também temeram as conquistas alemãs sobre o Pacífico e questionaram a posse de Samoa, conseguindo que as ilhas fossem repartidas em 1899 entre os dois países (CAMPBELL, 2003). Em 1898, os Estados Unidos anexaram o Havaí e conquistaram Guam após a vitória na Guerra Hispano-Americana sobre a Espanha, que por sua vez vendeu as Ilhas Marianas, Carolinas e Palau para a Alemanha. O Chile ocupou Rapa Nui (Ilha de Páscoa) em 1888, e por fim a Inglaterra tomou completamente as Ilhas Salomão, em 1893; impôs um protetorado formal sobre Tokelau, em 1889; sobre as Ilhas Cook, em 1888; e sobre Niue e Tonga, em 1900; e estabeleceu um condomínio com a França sobre as Novas Hébridas, em 1906 (McINTYRE, 2014). ${ }^{14}$

Em relativamente pouco tempo, todo o continente foi anexado pelas potências europeias e pelos Estados Unidos. ${ }^{15}$ Iniciou-se, assim, a segunda e principal fase colonialista da Oceania. Fase essa também de intensa colonização linguística. Para Mariani (2004, p. 28),

[...] a colonização linguística [...] produz modificações em sistemas linguísticos que vinham se constituindo em separado, ou ainda, provoca reorganizações no funcionamento linguístico das línguas e rupturas em processos semânticos estabilizados. Colonização linguística resulta de um processo histórico de encontro entre pelo menos dois imaginários linguísticos constitutivos de povos culturalmente distintos - línguas com memórias, histórias e políticas de sentidos desiguais, em condições de produção tais que uma dessas línguas - chamada de língua colonizadora - visa impor-se sobre a(s) outra(s), colonizada(s).

14 O Japão também manteve uma política imperialista sobre a Oceania, anexando as Ilhas Ogasawara, em 1891 e ocupando grandes áreas do continente, principalmente na Micronésia, entre as duas guerras mundiais (LAL; FORTUNE, 2000).

15 A colonização europeia na Oceania encontrou diversas resistências entre os povos autóctones do continente como: a resistência dos indígenas australianos nos séculos XIX e XX; as guerras neozelandesas contra os maoris entre 1845 e 1872; a revolta durante a conquista de Fiji em 1878; a rebelião na Ilha Sokehs, em Pohnpei, contra a administração colonial alemã; as rebeliões em Rapa Nui (Ilha de Páscoa) em 1914 e 1964 por maior autonomia e direitos civis; a guerrilha kanak a partir de 1917 na Nova Caledônia; a rebelião em Malaita, nas Ilhas Salomão em 1927; a greve geral em Rabaul na Papua Nova Guiné em 1929; o movimento pela independência da Papua Ocidental a partir de 1965 e os movimentos de resistência em Samoa com a fundação da organização "O le Mau" em 1926, cujo lema era "Samoa para os samoanos". Em 28 de dezembro de 1929, onze samoanos foram mortos pela polícia europeia durante uma manifestação, no acontecimento que ficou conhecido como "sábado negro". Esse intenso movimento de resistência à colonização em Samoa, sem dúvidas, foi um dos fatores que fez com que o país fosse o primeiro no continente, depois da Austrália e da Nova Zelândia a conquistar sua independência em 1962 (FIRTH, 1997; CHAPPELL, 2013a; 2013b; GOTT, 2013; FOERSTER; PAKARATI, 2016). 
Essa modificação nos sistemas linguísticos locais se iniciou com as missões religiosas, que, apesar de terem começado no século XVII, se intensificaram no século XIX, permanecendo em muitos países até hoje. De acordo com Mühlhäusler (1996) a quantidade de missões com a diversidade de credos e métodos empregados na cristianização da região é algo bastante complexo de estudar e descrever, sobretudo em um continente com alta diversidade linguística. As ilhas do Pacífico receberam missionários católicos e protestantes vindos da Europa, dos Estados Unidos e da própria Oceania que, assim como as potências coloniais, disputavam espaços de influência religiosa e também divergiam sobre a melhor forma de cristianizar a população local. ${ }^{16}$

Contudo, é possível levantar um ponto em comum entre todos os missionários do século XIX, ainda que a melhor forma de cristianizar fosse aquela que utilizasse as línguas locais: para eles as línguas da Oceania eram primitivas e por isso incapazes de serem empregadas para transmitir ensinamentos e conceitos cristãos. Mariani (2004, p. 25) observou o mesmo entre os missionários europeus no Brasil, o que denominou de "ideologia do deficit", em que "ao mesmo tempo, é tanto já existente e prévia ao contato propriamente dito quanto serve para legitimar a forma como a dominação se processa".

Para superar essa incapacidade das línguas indígenas, Mühlhäusler (1996) apontou três alternativas de colonização linguística que foram adotadas pelos missionários e que, por sua vez, afetaram completamente o ambiente linguístico do continente: a) a utilização de línguas francas locais; b) a utilização de pidgins e crioulos ou c) a utilização de línguas europeias.

A primeira alternativa a ser empregada consistia em escolher de forma arbitrária línguas que seriam utilizadas como francas, adaptá-las, modernizá-las para representar a realidade cristã e promovê-las entre os habitantes de uma determinada região. Tal iniciativa, de acordo com Mühlhäusler (1996), se baseava na adoção de um sistema de escrita utilizando o alfabeto latino, na elaboração de uma gramática e de um dicionário e na tradução da Bíblia, que muitas vezes ignoravam

[...] as intuições metalinguísticas dos falantes que distinguem um número de entidades diferentes (às vezes nomeadas); diferenças linguísticas que servem importantes funções sociais (como diferenças nas formas de tratamento entre pessoas); o fato de que a questão da inteligibilidade mútua depende de outros fatores além de falar uma mesma língua (MÜHLÄUSLER, 1996, p. 145, tradução nossa) ${ }^{17}$.

16 Para termos uma ideia sobre essa diversidade, entre os missionários católicos estavam jesuítas, maristas e dos Sagrados Corações de Jesus e de Maria e entre os protestantes havia membros da London Missionary Society (LMS) e da American Board of Commissioners for Foreign Missions (ABCFM) - formadas por protestantes anglicanos, presbiterianos e batistas — além de metodistas wesleyanos, anglicanos, presbiterianos, luteranos adventistas e mórmons. Cabe destacar que os missionários conseguiram a conversão de alguns reinos ao Cristianismo como Taiti (1815); Tonga, Havaí (1830) e Fiji (1854) (LAL; FORTUNE, 2000; CAMPBELL, 2003; GRAIG, 2011; SNIJDERS, 2012).

17 No original: [...] "the metalinguistic intuitions of the speakers that distinguish the number of different (sometimes named) entities; linguistic differences which serve important social functions such as indexing group differences; the 
Tais ações tiveram como consequência "a promoção de uma língua (ou variante) que tradicionalmente não era dominante; a criação de hierarquias entre as línguas; a modificação dos vernáculos locais; o silenciamento gradual daqueles que falavam outras línguas" (MÜHLÄUSLER, 1996, p. 150) e, acrescentaríamos, o extermínio gradual de línguas próximas. Como exemplo dessa forma de cristianização, Mühlhäusler (1996) aponta o emprego do taitiano na colonização de Rapa Nui e o emprego do samoano na colonização de Tuvalu, neste último criando uma situação diglóssica entre o tuvaluano e o samoano durante a colonização - em que o governo colonial local utilizava a segunda língua em seus atos oficiais - o que afetou o léxico e a gramática da língua tuvaluana tradicional.

A segunda alternativa era a utilização de um pidgin ou de um crioulo. De início essa alternativa foi bastante criticada pelos missionários devido à sua falta de padronização, à constante modificação, e até à concepção de que tais línguas poderiam trazer influências negativas do Ocidente para os nativos (MÜHLÄUSLER, 1996). ${ }^{18}$ No entanto, essa alternativa passou a ser mais aceita quando os missionários se depararam com a situação linguística da Melanésia que, como dissemos, tem uma das maiores diversidades linguísticas do mundo. Tais críticas foram-se reduzindo no avançar do século XX, com o aumento do número de falantes dessas línguas no continente. ${ }^{19}$

Já a terceira alternativa, a de utilização de línguas europeias, de acordo com Mühlhäusler (1996) tinha pontos positivos para os missionários. Ele levanta a capacidade dessas línguas em expressar a mensagem da Bíblia, a possível relação entre nacionalismo (linguístico) e os processos civilizatório e de cristianização, a capacidade de atrair mais missionários pela não necessidade de aprender a língua local e a redução dos custos na produção de materiais didáticos em um número bem menor de línguas. Além disso, tal alternativa tornou-se ainda mais atrativa para eles com o avanço do imperialismo quando passaram a ganhar subvenções das metrópoles europeias para disseminar suas línguas nacionais.

Todavia, independentemente do método utilizado na colonização, se, por um lado, Mühlhäusler (1996) afirma que todos privilegiavam a comunicação, intervindo, inclusive, na constituição dessas línguas no pós-colonialismo, vamos mais adiante ao afirmar que a colonização linguística "se impõe pela força e pela escrita, ou melhor, impõe-se com a força institucionalizadora de uma língua (europeia) escrita gramatizada que já traz consigo uma memória, a memória do colonizador sobre a sua própria história e a sua própria língua" (MARIANI, 2004, p. 24). Todas as alternativas empregadas, assim, produziram modificações nas línguas locais, seja na simples adoção de uma

fact that questions of mutual intelligibility depend on factors other than having a common name" (MÜHLÄUSLER, 1996, p. 145).

18 Aqui, novamente, observamos o funcionamento da "ideologia do déficit", que inferiorizava as línguas pidgins e crioulas.

19 Mühlhäusler (1996) atribui, inclusive, certa importância aos missionários para o desenvolvimento de alguns pidgins e crioulos (tanto quanto o sistema de plantations, empregado em diversas regiões, que promovia deslocamentos de nativos pelo continente), como o crioulo do norte da Austrália, o unserdeutsch, o tayo e a estabilização do tok pisin. 
escrita ocidental, ${ }^{20}$ ou na produção de alterações no campo semântico, que trazem essa memória do colonizador, produzindo outras redes de sentido entre o colonizado e o colonizador. ${ }^{21}$

Com o avanço do imperialismo europeu e estadunidense sobre o Pacífico e o estabelecimento de colônias por toda a região, foram criadas estruturas, entidades e instituições estatais para exercer o controle das metrópoles, como foi feito na África. No início do século XX, intensificaram-se, assim, a proibição no continente oceânico das línguas locais e a implantação de políticas de imposição das línguas europeias como únicas possíveis. Isso ocorre até a independência dos países nos anos 1960 e 1970 ou até o reconhecimento de direitos culturais e linguísticos em países já independentes, como a Austrália e a Nova Zelândia.

Tal mudança também ocorreu em outras partes do mundo, e só foi possível por meio dos movimentos de independência e descolonização no restante da Oceania, que ganharam força após o fim da II Guerra Mundial e após a criação da ONU em 1945, com a difusão do princípio da autodeterminação dos povos. Foi justamente na década de 1960 que a maioria dos países africanos conquistou sua independência e que os primeiros países da Oceania, após a Austrália e Nova Zelândia, conquistaram suas autonomias: Samoa, em 1962, e Nauru, em 1968. ${ }^{22}$

Como em todos os outros países que conquistaram sua independência após um processo histórico de colonização, os novos países da Oceania encontraram pela frente muitos desafios de natureza econômica, política, social e também linguística. Qual língua oficial adotar para o novo país, muitas vezes forjado com base no colonialismo? Qual a melhor forma de promover o desenvolvimento social e erradicar o analfabetismo nos países com grande diversidade linguística da Melanésia e nos pequenos países com baixa diversidade linguística, mas com poucos falantes na Micronésia ou na Polinésia? Como promover as línguas indígenas como forma de expressão desses grupos? Como lidar com o legado da(s) língua(s) do colonizador e sua relação com a(s) língua(s) do colonizado? Como agir em um mundo cada vez mais globalizado, conectado por meio da internet e com transformações tecnológicas crescentes? Como vencer tais obstáculos

20 Segundo Mugler e Lynch (1996), nenhuma língua da Oceania era escrita até os europeus chegarem.

${ }^{21}$ Um exemplo dessas complexas redes de sentido de língua entre o colonizado e o colonizador é o movimento milenarista cargo cult, cujo estudo antropológico e sociolinguístico, inclusive, colaborou para o desenvolvimento de pesquisas na área de letramento e aquisição da escrita em outras partes do mundo. De acordo com Meggitt e Burridge (MÜHLHÄUSLER, 1996), esse movimento surgiu na Melanésia, sobretudo na Papua-Nova Guiné, a partir da observação por grupos autóctones de que missionários, comerciantes, latifundiários e oficiais coloniais recebiam carregamentos de alimentos e de produtos ocidentais, por meio de navios e aviões, após o envio de cartas e sem a necessidade imediata do uso de moeda ou mesmo escambo. A relevância de tal movimento para os estudos de letramento passa justamente pelo sentido dado à escrita pelos nativos e pelo questionamento de que o aprendizado da escrita não garantiria a eles por si só o poder de enviar cartas para receber produtos e objetos, como ocorria com missionários e oficiais europeus.

22 De acordo com MacLellan (2016), na última década, pode-se observar uma nova onda independentista no continente. O estado de Chuuk (Micronésia), o arquipélago de Bougainville (Papua-Nova Guiné) e a Nova Caledônia (França) poderão ser os próximos países independentes, após a decisão de seus habitantes em plebiscitos a serem realizados entre 2019 e 2020. Além disso, a Polinésia Francesa retornou à Lista da ONU de territórios não autônomas, em 2013, após intensa diplomacia dos países da Oceania. 
com a escassez de recursos financeiros? Qual(is) a(s) melhor(es) política(s) linguística(s) a ser(em) adotada(s) para esse continente com situação linguística tão complexa?

São tais questões que nos inquietaram e nos estimularam a desenvolver a pesquisa.

\section{A política linguística da Oceania no pós-independência}

Como pudemos observar na primeira parte deste artigo, todas as línguas estão em constantes transformações sob intervenção humana. Calvet (2002) distingue essas transformações em dois processos de gestão: a gestão in vivo e a gestão in vitro. A gestão in vivo são as transformações ocorridas naturalmente em toda e qualquer língua, como variantes linguísticas, baseadas na idade, gênero ou região. Já a gestão in vitro ocorre quando é imposta a uma língua alguma mudança, geralmente pelo Estado. Essa imposição visa modificar o ambiente linguístico de uma situação linguística A para uma situação linguística B. E, ainda assim, Calvet (2002) afirma não haver garantias de sucesso, pois o êxito de uma política linguística para ele depende do grau de aceitabilidade do falante.

Tais ações políticas que visam modificar uma situação linguística, segundo Kloss (1969), podem ser classificadas como política linguística de corpus e política linguística de status. Enquanto a primeira está relacionada a uma planificação formal da língua, uma mudança no corpo da língua, isto é, quando uma língua é equipada, seja em seu léxico, gramática ou grafia para assumir outra função, a segunda relaciona-se às funções que uma língua pode ter em relação às outras e em um determinado ambiente linguístico. Cooper (1997) propõe uma terceira categoria: a política linguística de aquisição que, para ele, seriam as ações feitas para que se amplie o número de usuários de uma língua. Uma vez dito isso, passemos à análise da atual situação linguística da Oceania.

Para realizarmos esse levantamento sobre as políticas linguísticas do continente, consultamos diversas fontes, como a legislação e órgãos de estatísticas e de educação dos países e territórios da Oceania, além de vários autores listados na bibliografia, mas em especial Leclerc (2018). Depois, elaboramos a seguinte tabela, inspirada em outra feita por Ouane (2003) e Barbosa da Silva (2011) para a situação linguística dos países africanos, numa tentativa de apresentar de forma simplificada a conjuntura linguística nos países e territórios da Oceania.

Nas duas primeiras colunas, temos o nome do país ou território, com sua data de independência ou a informação de qual país é dependente e sua população com dados do UNFPA (2019). Na terceira coluna, temos o número de línguas faladas em todo o território, divididas em línguas alóctones e autóctones, além das principais, com dados do Ethnologue (2017). A quarta coluna apresenta uma lista com o nome das principais línguas, seja por ser a mais falada ou por ter caráter oficial. ${ }^{23}$ As duas colunas seguintes

23 Para nós, todo ato de nomear é um ato ideológico e o mesmo acontece com as línguas. Uma língua pode ter diversos nomes, de acordo com a posição ideológica de quem a nomeia, podendo ser chamada pela forma como a qual seus falantes a designam, pelo mesmo nome que se designa o seu grupo de falantes ou ainda pela forma como os europeus 
mostram o percentual da população que fala essas línguas seja como primeira língua ou como segunda língua. As últimas cinco colunas referem-se à possível ou não utilização dessas línguas no país, seja como língua oficial de jure ou de facto, como língua franca, isto é, língua de contato entre falantes de diferentes línguas locais, ou como língua de instrução ${ }^{24}$ na educação pré-primária, os quatro ou cinco primeiros anos de escolaridade; na primária, os quatro ou cinco anos posteriores e na média, três ou quatro anos antes do ensino superior.

Tabela 1 - Situação político-linguística da Oceania

\begin{tabular}{|c|c|c|c|c|c|c|c|c|c|c|c|c|}
\hline \multirow{3}{*}{$\begin{array}{c}\text { Países } \\
\text { (ano da } \\
\text { independência } \\
\text { ou país de qual } \\
\text { é dependente) }\end{array}$} & \multirow{3}{*}{$\begin{array}{c}\text { População } \\
\text { UNFPA } \\
\text { (milhões) }\end{array}$} & \multicolumn{3}{|c|}{$\begin{array}{l}\text { Número de línguas } \\
\text { Ethnologue } 2017\end{array}$} & \multirow{3}{*}{$\begin{array}{l}\text { Línguas } \\
\text { principais }\end{array}$} & \multicolumn{2}{|c|}{$\begin{array}{l}\text { Percentual de } \\
\text { falantes }\end{array}$} & \multicolumn{5}{|c|}{ Língua usada como } \\
\hline & & \multirow[b]{2}{*}{$\begin{array}{l}\text { Autó- } \\
\text { ctones }\end{array}$} & \multirow[b]{2}{*}{$\begin{array}{l}\text { Aló- } \\
\text { ctones }\end{array}$} & \multirow[b]{2}{*}{$\begin{array}{c}\text { Princi- } \\
\text { pais }\end{array}$} & & \multirow{2}{*}{$\begin{array}{c}\text { Primeira } \\
\text { língua }\end{array}$} & \multirow[b]{2}{*}{$\begin{array}{l}\text { Segunda } \\
\text { língua }\end{array}$} & \multirow[b]{2}{*}{$\begin{array}{c}\text { Língua } \\
\text { oficial }\end{array}$} & \multirow{2}{*}{$\begin{array}{l}\text { Língua } \\
\text { Franca }\end{array}$} & \multicolumn{3}{|c|}{ Instrução média } \\
\hline & & & & & & & & & & $\begin{array}{c}\text { Pré- } \\
\text { primário }\end{array}$ & Primário & Médio \\
\hline $\begin{array}{l}\text { Austrália } \\
\text { (1901) }\end{array}$ & 24,4 & 195 & $\begin{array}{c}+\mathrm{de} \\
150\end{array}$ & 1 & $\begin{array}{c}\text { Inglês } \\
\text { Chinês } \\
\text { Árabe } \\
\text { Catonês } \\
\text { Vietnamita } \\
\text { Italiano } \\
\text { Grego } \\
\text { Tagalo } \\
\text { Hindi } \\
\text { Espanhol } \\
\text { Punjabi } \\
\text { Persa } \\
\text { Coreano } \\
\text { Alemão } \\
\text { Tâmil } \\
\text { Francês } \\
\text { Línguas } \\
\text { autóctones }\end{array}$ & $\begin{array}{l}72,7 \\
2,6 \\
1,4 \\
1,2 \\
1,2 \\
1,2 \\
1,0 \\
0,8 \\
0,7 \\
0,6 \\
0,6 \\
0,5 \\
0,5 \\
0,3 \\
0,3 \\
0,3 \\
\\
0,3\end{array}$ & 21 & $\left|\begin{array}{c}\mathrm{X} \\
\text { (de facto })\end{array}\right|$ & $\mathrm{X}$ & $\mathrm{X}$ & $\mathrm{X}$ & $\mathrm{X}$ \\
\hline $\begin{array}{l}\text { Fiji } \\
(1970)\end{array}$ & 0,9 & 10 & 14 & 3 & $\begin{array}{c}\text { Inglês } \\
\text { Fijiano } \\
\text { Hindustani } \\
\text { Fijiano } \\
\text { ocidental } \\
\text { Tâmil } \\
\text { Telugu } \\
\text { Bhojpouri } \\
\text { Gujarati } \\
\text { Rotumano } \\
\text { Kiribatiano } \\
\text { Chinês }\end{array}$ & $\begin{array}{c}2,7 \\
35,1 \\
21,7 \\
9,5 \\
8,6 \\
3,6 \\
2,9 \\
2,7 \\
1,2 \\
0,7 \\
0,5\end{array}$ & 21 & $\begin{array}{c}\mathrm{X} \\
\mathrm{X} \\
\mathrm{X} \\
(\text { de facto })\end{array}$ & $\begin{array}{l}X \\
X \\
X\end{array}$ & $\begin{array}{l}X \\
X \\
X\end{array}$ & $\mathrm{X}$ & $\mathrm{X}$ \\
\hline
\end{tabular}

a chamaram. Por exemplo, a forma de designar a língua falada em Kiribati é uma tradução do inglês que por sua vez adveio da forma como os habitantes locais chamavam o país a partir do nome colonial em inglês Gilbert Islands, daí Kiribati, kiribatiano. Optamos, assim, a fim de padronizar os nomes das línguas neste artigo, por utilizar o termo em português, de acordo com o Dicionário Houaiss (2001), e caso não encontrássemos, por realizar a tradução para o português daquelas línguas nomeadas em inglês e por fim utilizar o nome do grupo étnico expresso no Ethnologue (2017) para aqueles que não foram nomeados em inglês.

24 Cabe ressaltar que consideramos língua de instrução, a língua utilizada na sala de aula para as mais diferentes disciplinas, inclusive as das ciências exatas. Não foram considerados, portanto, nessa categoria, países que incluam em suas grades curriculares línguas locais apenas como disciplinas. Do mesmo modo, projetos pilotos também não foram considerados. Ademais, levou-se em consideração neste caso também a realidade e não a legislação em vigor, que muitas vezes não é cumprida. 


\begin{tabular}{|c|c|c|c|c|c|c|c|c|c|c|c|c|}
\hline \multirow{3}{*}{$\begin{array}{c}\text { Países } \\
\text { (ano da } \\
\text { independência } \\
\text { ou país de qual } \\
\text { é dependente) }\end{array}$} & \multirow{3}{*}{$\begin{array}{c}\text { População } \\
\text { UNFPA } \\
\text { (milhões) }\end{array}$} & \multicolumn{3}{|c|}{$\begin{array}{l}\text { Número de línguas } \\
\text { Ethnologue } 2017\end{array}$} & \multirow{3}{*}{$\begin{array}{l}\text { Linguas } \\
\text { principais }\end{array}$} & \multicolumn{2}{|c|}{$\begin{array}{l}\text { Percentual de } \\
\text { falantes }\end{array}$} & \multicolumn{5}{|c|}{ Língua usada como } \\
\hline & & \multirow[b]{2}{*}{$\begin{array}{l}\text { Autó- } \\
\text { ctones }\end{array}$} & \multirow[b]{2}{*}{$\begin{array}{l}\text { Aló- } \\
\text { ctones }\end{array}$} & \multirow[b]{2}{*}{$\begin{array}{c}\text { Princi- } \\
\text { pais }\end{array}$} & & \multirow[b]{2}{*}{$\begin{array}{c}\text { Primeira } \\
\text { língua }\end{array}$} & \multirow[b]{2}{*}{$\begin{array}{l}\text { Segunda } \\
\text { lingua }\end{array}$} & \multirow[b]{2}{*}{$\begin{array}{c}\text { Língua } \\
\text { oficial }\end{array}$} & \multirow[b]{2}{*}{$\begin{array}{l}\text { Língua } \\
\text { Franca }\end{array}$} & \multicolumn{3}{|c|}{ Instrução média } \\
\hline & & & & & & & & & & \begin{tabular}{|c|} 
Pré- \\
primário
\end{tabular} & Primário & Médio \\
\hline $\begin{array}{l}\text { Guam } \\
\text { (EUA) }\end{array}$ & 0,164 & 1 & 7 & 3 & $\begin{array}{c}\text { Inglês } \\
\text { Chamorro } \\
\text { Tagalo } \\
\text { Chuquês } \\
\text { Coreano } \\
\text { Chinês } \\
\text { Japonês } \\
\text { Palauano }\end{array}$ & $\begin{array}{c}38,3 \\
22,2 \\
22,2 \\
3,4 \\
2,4 \\
1,9 \\
1,8 \\
1,4\end{array}$ & 61 & $\mid \begin{array}{c}\mathrm{X} \\
\mathrm{X} \\
\text { (de jure })\end{array}$ & $\mathrm{x}$ & $\begin{array}{l}X \\
X\end{array}$ & $\mathrm{X}$ & $\mathrm{X}$ \\
\hline Havaí ${ }^{25}$ (EUA) & 1,4 (2016) & 2 & $\begin{array}{c}+ \text { de } \\
100\end{array}$ & 3 & $\begin{array}{c}\text { Inglês } \\
\text { Japonês } \\
\text { Tagalo } \\
\text { Ilocano } \\
\text { Havaiano } \\
\text { Espanhol } \\
\text { Coreano } \\
\text { Chinês } \\
\text { Samoano } \\
\text { Crioulo } \\
\text { havaiano }\end{array}$ & $\begin{array}{c}74,6 \\
5 \\
5,4 \\
4 \\
1,7 \\
1,7 \\
1,6 \\
1,2 \\
1\end{array}$ & 50 & $\mid \begin{array}{c}\mathrm{X} \\
\\
\mathrm{X} \\
(\text { de jure })\end{array}$ & $\mathrm{X}$ & $\mathrm{X}$ & $\mathrm{X}$ & $\mathrm{X}$ \\
\hline $\begin{array}{c}\text { Ilha Christmas } \\
\text { (Austrália) }\end{array}$ & $\begin{array}{l}0,0018 \\
(2016)\end{array}$ & 0 & 6 & 3 & $\begin{array}{c}\text { Inglês } \\
\text { Chinês } \\
\text { Malaio das } \\
\text { Ilhas Cocos } \\
\text { Cantonês } \\
\text { Min nan }\end{array}$ & $\begin{array}{c}27,8 \\
17,2 \\
\\
17,2 \\
3,7 \\
1,5\end{array}$ & & $\left|\begin{array}{c}\mathrm{X} \\
(\text { de facto })\end{array}\right|$ & $\mathrm{X}$ & $\mathrm{X}$ & $\mathrm{X}$ & $\mathrm{X}$ \\
\hline $\begin{array}{l}\text { Ilha Norfolk } \\
\text { (Austrália) }\end{array}$ & $\begin{array}{l}0,0017 \\
(2016)\end{array}$ & 1 & 1 & 2 & $\begin{array}{c}\text { Inglês } \\
\text { Crioulo } \\
\text { norfuk } \\
\text { Fijiano } \\
\text { Tagalo } \\
\text { Chinês }\end{array}$ & $\begin{array}{c}45,5 \\
40,9 \\
2 \\
1 \\
0,7\end{array}$ & 50 & $\mid \begin{array}{c}\mathrm{X} \\
\mathrm{X} \\
\text { (de jure) }\end{array}$ & & $\mathrm{X}$ & $\mathrm{X}$ & $\mathrm{X}$ \\
\hline $\begin{array}{l}\text { Ilhas Cocos } \\
\text { (Austrália) }\end{array}$ & $\begin{array}{l}0,0005 \\
(2016)\end{array}$ & 0 & 2 & 2 & $\begin{array}{c}\text { Inglês } \\
\text { Malaio das } \\
\text { Ilhas Cocos }\end{array}$ & $\begin{array}{l}22,2 \\
69,6\end{array}$ & & $\left|\begin{array}{c}\mathrm{X} \\
(\text { de facto })\end{array}\right|$ & & $\mathrm{X}$ & $\mathrm{X}$ & $\mathrm{X}$ \\
\hline $\begin{array}{l}\text { Ilhas Cook } \\
\text { (Nova } \\
\text { Zelândia) }\end{array}$ & 0,0173 & 4 & 1 & 2 & $\begin{array}{c}\text { Inglês } \\
\text { Maori das } \\
\text { Ilhas Cook } \\
\text { Pukapuka } \\
\text { Penrhyn }\end{array}$ & $\begin{array}{c}3,8 \\
\\
88,6 \\
4,3 \\
3,2 \\
\end{array}$ & 90 & $\mid \begin{array}{c}\mathrm{X} \\
\mathrm{X} \\
\text { (de jure) }\end{array}$ & & $\begin{array}{l}X \\
X\end{array}$ & $\mathrm{X}$ & $\mathrm{X}$ \\
\hline $\begin{array}{c}\text { Ilhas Marianas } \\
\text { do Norte } \\
\text { (EUA) }\end{array}$ & 0,055 & 3 & 6 & 1 & $\begin{array}{c}\text { Inglês } \\
\text { Tagalo } \\
\text { Chinês } \\
\text { Chamorro } \\
\text { Caroliniano } \\
\text { Coreano } \\
\text { Palauano } \\
\text { Japonês }\end{array}$ & $\begin{array}{c}10,7 \\
24,3 \\
23,4 \\
22,2 \\
3,5 \\
3,4 \\
2,3 \\
1,5\end{array}$ & 85 & \begin{tabular}{|c}
$\mathrm{X}$ \\
\\
$\mathrm{X}$ \\
$\mathrm{X}$ \\
$($ de jure $)$
\end{tabular} & $\mathrm{X}$ & $\begin{array}{l}X \\
X\end{array}$ & $\begin{array}{l}X \\
X\end{array}$ & $\begin{array}{l}\mathrm{X} \\
\mathrm{X}\end{array}$ \\
\hline $\begin{array}{c}\text { Ilhas Marshall } \\
\text { (1986) }\end{array}$ & 0,053 & 1 & 3 & 2 & $\begin{array}{c}\text { Inglês } \\
\text { Marshallês } \\
\text { Japonês } \\
\text { Tagalo }\end{array}$ & $\begin{array}{c}6,8 \\
86,9 \\
0,6 \\
0,6\end{array}$ & 90 & $\mid \begin{array}{c}\mathrm{X} \\
\mathrm{X} \\
\text { (de facto })\end{array}$ & & $\begin{array}{l}X \\
X\end{array}$ & $\begin{array}{l}X \\
X\end{array}$ & $\begin{array}{l}\mathrm{X} \\
\mathrm{X}\end{array}$ \\
\hline
\end{tabular}

25 Uma pesquisa oficial elaborada pelo Governo do Estado do Havaí, em 2016, identificou que 74,6\% dos havaianos falam inglês em casa e que $25,4 \%$ falam outras línguas (HAWAII, 2016). Nesta mesma pesquisa, pela primeira vez, foi dado como alternativa de resposta o crioulo havaiano, que alcançou menos de $0,1 \%$. Contudo, de acordo com outros pesquisadores como Drager (2012), o número de falantes de crioulo ainda é impreciso, mas pode chegar a pelo menos metade da população havaiana, como segunda língua. Acreditamos, assim, que durante esse censo linguístico, grande parte dos falantes de crioulo não se autodeclarou, tendo respondido a questão como falantes de língua inglesa. 


\begin{tabular}{|c|c|c|c|c|c|c|c|c|c|c|c|c|}
\hline \multirow{3}{*}{$\begin{array}{c}\text { Países } \\
\text { (ano da } \\
\text { independência } \\
\text { ou país de qual } \\
\text { é dependente) }\end{array}$} & \multirow{3}{*}{$\begin{array}{c}\text { População } \\
\text { UNFPA } \\
\text { (milhões) }\end{array}$} & \multicolumn{3}{|c|}{$\begin{array}{l}\text { Número de línguas } \\
\text { Ethnologue } 2017\end{array}$} & \multirow{3}{*}{$\begin{array}{l}\text { Línguas } \\
\text { principais }\end{array}$} & \multicolumn{2}{|c|}{$\begin{array}{l}\text { Percentual de } \\
\text { falantes }\end{array}$} & \multicolumn{5}{|c|}{ Língua usada como } \\
\hline & & \multirow[b]{2}{*}{$\begin{array}{l}\text { Autó- } \\
\text { ctones }\end{array}$} & \multirow{2}{*}{$\begin{array}{c}\text { Aló- } \\
\text { ctones }\end{array}$} & \multirow[b]{2}{*}{$\begin{array}{l}\text { Princi- } \\
\text { pais }\end{array}$} & & \multirow{2}{*}{$\begin{array}{c}\text { Primeira } \\
\text { língua }\end{array}$} & \multirow{2}{*}{$\begin{array}{l}\text { Segunda } \\
\text { língua }\end{array}$} & \multirow{2}{*}{$\begin{array}{c}\text { Língua } \\
\text { oficial }\end{array}$} & \multirow{2}{*}{$\begin{array}{l}\text { Língua } \\
\text { Franca }\end{array}$} & \multicolumn{3}{|c|}{ Instrução média } \\
\hline & & & & & & & & & & $\begin{array}{c}\text { Pré- } \\
\text { primário }\end{array}$ & Primário & Médio \\
\hline $\begin{array}{l}\text { Ilhas Pitcairn }^{26} \\
\text { (Reino Unido) }\end{array}$ & 0,000055 & 1 & 1 & 2 & $\begin{array}{l}\text { Inglês } \\
\text { Crioulo } \\
\text { pitkern }\end{array}$ & & & $\left|\begin{array}{c}\mathrm{X} \\
\mathrm{X} \\
(\text { de facto })\end{array}\right|$ & & & & \\
\hline $\begin{array}{l}\text { Ilhas Salomão } \\
\text { (1978) }\end{array}$ & 0,611 & 73 & 3 & 1 & $\begin{array}{c}\text { Inglês } \\
\text { Pijin } \\
\text { (crioulo) } \\
\text { Kawara'ae } \\
\text { 'Are'are } \\
\text { Kiribatiano }\end{array}$ & $\begin{array}{c}2 \\
6 \\
8 \\
4,5 \\
1\end{array}$ & $\begin{array}{l}37 \\
76\end{array}$ & $\mid \begin{array}{c}\mathrm{X} \\
(\text { de facto })\end{array}$ & X & $\begin{array}{l}X \\
\\
X \\
X\end{array}$ & X & $X$ \\
\hline $\begin{array}{l}\text { Kiribati } \\
(1979)\end{array}$ & 0,116 & 1 & 3 & 2 & $\begin{array}{c}\text { Inglês } \\
\text { Kiribatiano } \\
\text { Tuvaluano } \\
\text { Chinês } \\
\end{array}$ & $\begin{array}{c}2 \\
97 \\
0,5\end{array}$ & 26 & $\left|\begin{array}{c}\mathrm{X} \\
\mathrm{X} \\
(\text { de facto })\end{array}\right|$ & $\mathrm{X}$ & $X$ & $X$ & $\mathrm{X}$ \\
\hline $\begin{array}{l}\text { Micronésia }^{27} \\
\text { (1986) }\end{array}$ & 0,105 & 18 & 2 & 1 & $\begin{array}{c}\text { Inglês } \\
\text { Chuquês } \\
\text { Pohnpeiano } \\
\text { Kosraeano } \\
\text { Yapês } \\
\end{array}$ & $\begin{array}{c}1,8 \\
52,3 \\
25,9 \\
7 \\
5,6\end{array}$ & $\begin{array}{c}45,1 \\
4,8 \\
6,9 \\
0,5 \\
0,3 \\
\end{array}$ & $\mid \begin{array}{c}\mathrm{X} \\
(\text { de facto })\end{array}$ & $X$ & $\begin{array}{l}\mathrm{X} \\
\mathrm{X} \\
\mathrm{X} \\
\mathrm{X} \\
\mathrm{X}\end{array}$ & $\mathrm{X}$ & $\mathrm{X}$ \\
\hline $\begin{array}{l}\text { Nauru } \\
(1968)\end{array}$ & 0,011 & 1 & 7 & 2 & $\begin{array}{c}\text { Inglês } \\
\text { Nauruano } \\
\text { Kiribatiano } \\
\text { Chinês } \\
\text { Tuvaluano } \\
\text { Marshallês } \\
\text { Kosraeano } \\
\end{array}$ & $\begin{array}{c}2 \\
90 \\
2 \\
2 \\
1\end{array}$ & $\begin{array}{c}64 \\
5\end{array}$ & $\mid \begin{array}{c}\mathrm{X} \\
\mathrm{X} \\
(\text { de facto })\end{array}$ & $X$ & $\begin{array}{l}X \\
X\end{array}$ & $X$ & $X$ \\
\hline $\begin{array}{c}\text { Niue } \\
\text { (Nova } \\
\text { Zelândia) }\end{array}$ & 0,0016 & 1 & 2 & 2 & $\begin{array}{l}\text { Inglês } \\
\text { Niueano } \\
\text { Tonganês }\end{array}$ & $\begin{array}{l}21,3 \\
76,6\end{array}$ & $\begin{array}{c}32,4 \\
16\end{array}$ & $\mid \begin{array}{c}\mathrm{X} \\
\mathrm{X} \\
(\text { de facto })\end{array}$ & $X$ & $\begin{array}{l}X \\
X\end{array}$ & $\mathrm{X}$ & $X$ \\
\hline $\begin{array}{c}\text { Nova } \\
\text { Caledônia } \\
\text { (França) }\end{array}$ & 0,276 & 34 & 7 & 1 & $\begin{array}{c}\text { Francês } \\
\text { Wallisiano } \\
\text { Drehu } \\
\text { Italiano } \\
\text { Nengone } \\
\text { Paicî } \\
\text { Taitiano } \\
\text { Xârâcùù } \\
\text { Ajië } \\
\text { Iaai } \\
\end{array}$ & $\begin{array}{c}25,7 \\
8,8 \\
4,9 \\
3,9 \\
3,2 \\
2,8 \\
2,6 \\
2,1 \\
2 \\
1,7\end{array}$ & 70 & $\mid \begin{array}{c}\mathrm{X} \\
(\text { de jure })\end{array}$ & $X$ & $X$ & $X$ & $X$ \\
\hline $\begin{array}{c}\text { Nova Zelândia } \\
\text { (1907) }\end{array}$ & 4,7 & 2 & + de 70 & 2 & \begin{tabular}{|c|} 
Inglês \\
Maori \\
Samoano \\
Hindi \\
Chinês \\
Francês \\
Yue \\
Alemão \\
Tonganês \\
Tagalo \\
Africâner \\
Espanhol \\
Coreano \\
Neerlandês \\
Língua \\
de sinais \\
neozelandesa
\end{tabular} & $\begin{array}{l}81 \\
3,7 \\
2,2 \\
1,7 \\
1,3 \\
1,2 \\
1,1 \\
0,9 \\
0,8 \\
0,7 \\
0,7 \\
0,6 \\
0,6 \\
0,6 \\
\\
0,5\end{array}$ & 15 & $\begin{array}{c}\mathrm{X} \\
\mathrm{X} \\
(\text { de jure })\end{array}$ & $\mathrm{X}$ & $\begin{array}{l}X \\
X \\
X\end{array}$ & $\begin{array}{l}X \\
X \\
X\end{array}$ & $\begin{array}{l}X \\
X\end{array}$ \\
\hline
\end{tabular}

26 A pequena população das Ilhas Pitcairn não permite que se elabore estatística. Além disso, as ilhas apenas fornecem ensino escolar até os 12 anos de idade. Em diante, o jovem deve estudar na Nova Zelândia (LECLERC, 2018).

27 A Micronésia está dividida administrativamente em quatro estados. Cada estado tem a sua língua oficial, sendo que o inglês é oficial em todos ao lado do chuquês no estado de Chuuk, do kosraeano no estado de Kosrae, do pohnpeiano no estado de Pohnpei e das línguas autóctones no estado de Yap. 


\begin{tabular}{|c|c|c|c|c|c|c|c|c|c|c|c|c|}
\hline \multirow{3}{*}{$\begin{array}{c}\text { Países } \\
\text { (ano da } \\
\text { independência } \\
\text { ou país de qual } \\
\text { é dependente) }\end{array}$} & \multirow{3}{*}{$\begin{array}{c}\text { População } \\
\text { UNFPA } \\
\text { (milhões) }\end{array}$} & \multicolumn{3}{|c|}{$\begin{array}{l}\text { Número de línguas } \\
\text { Ethnologue } 2017\end{array}$} & \multirow{3}{*}{$\begin{array}{l}\text { Línguas } \\
\text { principais }\end{array}$} & \multicolumn{2}{|c|}{$\begin{array}{l}\text { Percentual de } \\
\text { falantes }\end{array}$} & \multicolumn{5}{|c|}{ Língua usada como } \\
\hline & & \multirow{2}{*}{$\begin{array}{l}\text { Autó- } \\
\text { ctones }\end{array}$} & \multirow{2}{*}{$\begin{array}{l}\text { Aló- } \\
\text { ctones }\end{array}$} & \multirow{2}{*}{$\begin{array}{c}\text { Princi- } \\
\text { pais }\end{array}$} & & \multirow{2}{*}{$\begin{array}{c}\text { Primeira } \\
\text { língua }\end{array}$} & \multirow{2}{*}{$\begin{array}{l}\text { Segunda } \\
\text { língua }\end{array}$} & \multirow{2}{*}{$\begin{array}{l}\text { Língua } \\
\text { oficial }\end{array}$} & \multirow{2}{*}{$\begin{array}{l}\text { Língua } \\
\text { Franca }\end{array}$} & \multicolumn{3}{|c|}{ Instrução média } \\
\hline & & & & & & & & & & $\begin{array}{c}\text { Pré- } \\
\text { primário }\end{array}$ & Primário & Médio \\
\hline Palau $^{28}$ (1994) & 0,021 & 3 & 3 & 2 & $\begin{array}{c}\text { Inglês } \\
\text { Palauano } \\
\text { Tagalo } \\
\text { Sonsorolês } \\
\text { Angaur } \\
\text { Japonês } \\
\text { Tobiano }\end{array}$ & $\begin{array}{c}19 \\
68 \\
10 \\
3 \\
\\
0,7 \\
0,1\end{array}$ & 79 & $\begin{array}{c}\mathrm{X} \\
\mathrm{X} \\
(\text { de jure })\end{array}$ & & $\begin{array}{l}X \\
X\end{array}$ & $\begin{array}{l}X \\
X\end{array}$ & $\begin{array}{l}X \\
X\end{array}$ \\
\hline $\begin{array}{c}\text { Papua } \\
\text { (Indonésia) }\end{array}$ & $\begin{array}{c}3,67 \\
(2016)\end{array}$ & 262 & 1 & 2 & $\begin{array}{l}\text { Indonésio } \\
\text { Crioulo } \\
\text { malaio- } \\
\text { papuásio } \\
\text { Dani } \\
\text { ocidental } \\
\text { Ekari } \\
\text { ocidental } \\
\text { Javanês }\end{array}$ & $\begin{array}{c}36,5 \\
12,5 \\
8,1 \\
4,5 \\
2,6\end{array}$ & 14 & $\left|\begin{array}{c}\mathrm{X} \\
(\text { de facto })\end{array}\right|$ & $\begin{array}{l}X \\
X\end{array}$ & $\mathrm{X}$ & $\mathrm{X}$ & $\mathrm{X}$ \\
\hline $\begin{array}{c}\text { Papua-Nova } \\
\text { Guiné } \\
\text { (1975) }\end{array}$ & 8,2 & 839 & 2 & 3 & \begin{tabular}{|c|} 
Inglês \\
Tok pisin \\
Hiri motu \\
Melpa \\
Huli \\
Língua de \\
sinais da \\
Papua Nova \\
Guiné
\end{tabular} & $\begin{array}{c}1 \\
2 \\
3 \\
2,4 \\
2\end{array}$ & $\begin{array}{c}5 \\
64\end{array}$ & $\begin{array}{c}\mathrm{X} \\
\mathrm{X} \\
\mathrm{X} \\
(\text { defacto }) \\
\\
\\
\\
\mathrm{X}\end{array}$ & $\mathrm{X}$ & $\begin{array}{l}X \\
X \\
X \\
X \\
X\end{array}$ & $\mathrm{X}$ & $\mathrm{X}$ \\
\hline $\begin{array}{c}\text { Papua }^{29} \\
\text { Ocidental } \\
\text { (Indonésia) }\end{array}$ & $\begin{array}{c}1,36 \\
(2016)\end{array}$ & 57 & 1 & 2 & $\begin{array}{l}\text { Indonésio } \\
\text { Crioulo } \\
\text { malaio- } \\
\text { papuásio } \\
\text { Javanês } \\
\text { Mai Brat } \\
\text { Hatam }\end{array}$ & $\begin{array}{c}69,7 \\
22,5 \\
6,2 \\
3,5 \\
2,6\end{array}$ & 27 & $\mid \begin{array}{c}\mathrm{X} \\
(\text { de facto })\end{array}$ & $\begin{array}{l}X \\
X\end{array}$ & $\mathrm{X}$ & $\mathrm{X}$ & $\mathrm{X}$ \\
\hline $\begin{array}{l}\text { Polinésia } \\
\text { Francesa } \\
\text { (França) }\end{array}$ & 0,283 & 7 & 2 & 2 & \begin{tabular}{|c|} 
Francês \\
Taitiano \\
Tuamotuano \\
Chinês hakka \\
Austral \\
Norte- \\
marquesano \\
Sul- \\
marquesano \\
Mangarevano
\end{tabular} & $\begin{array}{c}30 \\
44 \\
8 \\
4,7 \\
2,6 \\
\\
\\
1,4 \\
1,3 \\
0,8\end{array}$ & $\begin{array}{l}35 \\
30\end{array}$ & $\begin{array}{c}\mathrm{X} \\
(\text { de jure })\end{array}$ & $\begin{array}{l}X \\
X\end{array}$ & $\mathrm{X}$ & $\mathrm{X}$ & $\mathrm{X}$ \\
\hline $\begin{array}{c}\text { Rapa Nui } \\
\text { /Ilha de Páscoa } \\
\text { (Chile) }\end{array}$ & 0,0077 & 1 & 1 & 2 & $\begin{array}{l}\text { Espanhol } \\
\text { Rapa Nui }\end{array}$ & $\begin{array}{c}78 \\
13,8\end{array}$ & $\begin{array}{l}19 \\
33\end{array}$ & $\begin{array}{c}\mathrm{X} \\
(\text { de jure })\end{array}$ & $\mathrm{X}$ & $\begin{array}{l}X \\
X\end{array}$ & $\mathrm{X}$ & $\mathrm{X}$ \\
\hline $\begin{array}{l}\text { Samoa } \\
(1962)\end{array}$ & 0,196 & 1 & 3 & 2 & $\begin{array}{c}\text { Inglês } \\
\text { Samoano } \\
\text { Maori } \\
\text { Chinês }\end{array}$ & $\begin{array}{c}5 \\
93 \\
0,1 \\
0,1\end{array}$ & $\begin{array}{l}57 \\
6,7\end{array}$ & $\mid \begin{array}{c}\mathrm{X} \\
\mathrm{X} \\
(\text { de facto })\end{array}$ & $\mathrm{X}$ & $\mathrm{X}$ & $\begin{array}{l}X \\
X\end{array}$ & $\mathrm{X}$ \\
\hline
\end{tabular}

28 Palau está dividido administrativamente em 16 estados. Cada estado tem a sua língua oficial, sendo que o inglês é oficial em todos ao lado do tobiano no estado de Tobi, do sonsorolês no estado de Sonsorol, do japonês e do angaur no estado de Angaur e do palauano nos demais estados.

29 Sobre o percentual de falantes maternos de indonésio e do crioulo malaio-papuásio para os territórios da Papua e da Papua Ocidental coletamos dados, respectivamente, do Censo Indonésio de 2010 e de Kluge (2014). Mesmo que tais dados quando confrontados pareçam divergentes, optamos por mantê-los conforme essas referências. 


\begin{tabular}{|c|c|c|c|c|c|c|c|c|c|c|c|c|}
\hline \multirow{3}{*}{$\begin{array}{c}\text { Países } \\
\text { (ano da } \\
\text { independência } \\
\text { ou país de qual } \\
\text { é dependente) }\end{array}$} & \multirow{3}{*}{$\begin{array}{c}\text { População } \\
\text { UNFPA } \\
\text { (milhões) }\end{array}$} & \multicolumn{3}{|c|}{$\begin{array}{l}\text { Número de línguas } \\
\text { Ethnologue } 2017\end{array}$} & \multirow{3}{*}{$\begin{array}{l}\text { Línguas } \\
\text { principais }\end{array}$} & \multicolumn{2}{|c|}{$\begin{array}{l}\text { Percentual de } \\
\text { falantes }\end{array}$} & \multicolumn{5}{|c|}{ Língua usada como } \\
\hline & & \multirow{2}{*}{$\begin{array}{l}\text { Autó- } \\
\text { ctones }\end{array}$} & \multirow{2}{*}{$\begin{array}{l}\text { Aló- } \\
\text { ctones }\end{array}$} & \multirow{2}{*}{$\begin{array}{c}\text { Princi- } \\
\text { pais }\end{array}$} & & \multirow{2}{*}{$\begin{array}{c}\text { Primeira } \\
\text { língua }\end{array}$} & \multirow{2}{*}{$\begin{array}{c}\text { Segunda } \\
\text { língua }\end{array}$} & \multirow{2}{*}{$\begin{array}{l}\text { Língua } \\
\text { oficial }\end{array}$} & \multirow{2}{*}{$\begin{array}{l}\text { Língua } \\
\text { Franca }\end{array}$} & \multicolumn{3}{|c|}{ Instrução média } \\
\hline & & & & & & & & & & \begin{tabular}{|c|} 
Pré- \\
primário
\end{tabular} & Primário & Médio \\
\hline $\begin{array}{c}\text { Samoa } \\
\text { Americana } \\
\text { (EUA) }\end{array}$ & 0,055 & 2 & 4 & 2 & $\begin{array}{c}\text { Inglês } \\
\text { Samoano } \\
\text { Tonganês } \\
\text { Japonês } \\
\text { Tagalo }\end{array}$ & $\begin{array}{c}2 \\
91 \\
3,2 \\
3 \\
1,3\end{array}$ & 96 & $\begin{array}{c}\mathrm{X} \\
\mathrm{X} \\
\text { (de facto })\end{array}$ & $\mathrm{X}$ & $\begin{array}{l}X \\
X\end{array}$ & $\begin{array}{l}X \\
X\end{array}$ & $\mathrm{X}$ \\
\hline $\begin{array}{l}\text { Tonga } \\
(1970)\end{array}$ & 0,108 & 2 & 2 & 2 & $\begin{array}{c}\text { Inglês } \\
\text { Tonganês } \\
\text { Chinês } \\
\text { Niuafo'ou }\end{array}$ & $\begin{array}{c}1 \\
96 \\
2 \\
1\end{array}$ & 87 & $\begin{array}{c}\mathrm{X} \\
\mathrm{X} \\
\text { (de facto })\end{array}$ & $\mathrm{X}$ & $\begin{array}{l}X \\
X\end{array}$ & $\begin{array}{l}X \\
X\end{array}$ & $\mathrm{X}$ \\
\hline $\begin{array}{l}\text { Toquelau }^{30} \\
\text { (Nova } \\
\text { Zelândia) }\end{array}$ & 0,0013 & 1 & 3 & 2 & \begin{tabular}{|c|} 
Inglês \\
Toquelauano \\
Samoano \\
Tuvaluano
\end{tabular} & $\begin{array}{c}1 \\
93,4 \\
10,5 \\
4,5\end{array}$ & $\begin{array}{c}57,4 \\
2,7 \\
31,5 \\
2,7\end{array}$ & $\begin{array}{c}\mathrm{X} \\
\mathrm{X} \\
\text { (de facto) }\end{array}$ & $\mathrm{X}$ & $\mathrm{X}$ & $\mathrm{X}$ & \\
\hline $\begin{array}{l}\text { Tuvalu } \\
(1978)\end{array}$ & 0,011 & 1 & 2 & 2 & $\begin{array}{c}\text { Inglês } \\
\text { Tuvaluano } \\
\text { Kiribatiano }\end{array}$ & $\begin{array}{c}0,5 \\
95 \\
2\end{array}$ & $\begin{array}{c}86 \\
3\end{array}$ & $\begin{array}{c}\mathrm{X} \\
\mathrm{X} \\
\text { (de facto })\end{array}$ & $\mathrm{X}$ & $\begin{array}{l}X \\
X\end{array}$ & $\mathrm{X}$ & $\mathrm{X}$ \\
\hline $\begin{array}{l}\text { Vanuatu } \\
(1980)\end{array}$ & 0,276 & 107 & 8 & 3 & $\begin{array}{c}\text { Inglês } \\
\text { Francês } \\
\text { Bislama } \\
\text { Lenakel }\end{array}$ & $\begin{array}{c}2 \\
3,7 \\
4,1 \\
6\end{array}$ & $\begin{array}{c}60,3 \\
29,4 \\
83\end{array}$ & $\begin{array}{c}\mathrm{X} \\
\mathrm{X} \\
\mathrm{X} \\
(\text { de jure })\end{array}$ & $\begin{array}{l}X \\
X \\
X\end{array}$ & $\begin{array}{l}X \\
X \\
X \\
X\end{array}$ & $\begin{array}{l}X \\
X\end{array}$ & $\begin{array}{l}\mathrm{X} \\
\mathrm{X}\end{array}$ \\
\hline $\begin{array}{c}\text { Wallis e Futuna } \\
\text { (França) }\end{array}$ & 0,011 & 2 & 1 & 3 & $\begin{array}{c}\text { Francês } \\
\text { Wallisiano } \\
\text { Futunês }\end{array}$ & $\begin{array}{c}10,7 \\
58,9 \\
30\end{array}$ & 72 & $\mid \begin{array}{c}\mathrm{X} \\
\text { (de jure) }\end{array}$ & $\mathrm{X}$ & $\mathrm{X}$ & $\mathrm{X}$ & $\mathrm{X}$ \\
\hline
\end{tabular}

Fonte: Elaboração própria com base na legislação e websites de governos dos países e territórios da Oceania e em Leclerc (2018). ${ }^{30}$

De imediato, observando a quantidade de línguas presente em cada país ou território e levando em consideração a história colonial do continente, podemos dividi-los em quatro grupos ou categorias:

a) grupo do país com alta diversidade linguística (autóctone e alóctone) e que sofreu colonização de povoamento de base inglesa: Austrália;

b) grupo do país e territórios com baixa diversidade linguística autóctone, mas alta ou considerável diversidade linguística alóctone e que sofreram colonização de povoamento de base inglesa: Nova Zelândia e as desabitadas até os primeiros europeus chegarem, Ilha Norfolk e Ilhas Pitcairn;

c) grupo de países e territórios com baixo índice de diversidade linguística autóctone e que sofreram colonização de exploração: Guam, Havaí, Ilha Christmas, Ilhas Cocos, Ilhas Cook, Ilhas Marianas do Norte, Ilhas Marshall, Kiribati, Nauru, Niue, Palau, Polinésia Francesa, Rapa Nui, Samoa, Samoa Americana, Tokelau, Tonga, Tuvalu e Wallis e Futuna;

d) grupo de países e territórios com alto índice de diversidade linguística autóctone e que sofreram colonização de exploração: Fiji, Ilhas Salomão, Micronésia, Nova Caledônia, Papua, Papua Nova Guiné, Papua Ocidental e Vanuatu.

30 Nenhum dos três atóis de Tokelau tem uma instituição que fornece ensino médio. Os tokelauanos completam seus estudos em Samoa (LECLERC, 2018). 
No primeiro grupo, aquele com alta diversidade linguística autóctone e também alóctone, que foi colonizado por povoamento, está a Austrália, com cerca de 195 línguas indígenas e mais de 150 línguas imigrantes. Como dissemos na seção anterior, a política australiana sofreu uma profunda transformação nos anos 1970, quando o governo do país foi pressionado por movimentos aborígenes a abolir tanto a política de assimilação quanto a White Australia Policy, que barrava a imigração de descendentes não-europeus. Tais medidas permitiram a chegada dos primeiros asiáticos à Austrália e culminaram mais tarde com a adoção do multiculturalismo como política de Estado (MACINTYRE, 2009).

É a partir desse momento que se observa uma série de iniciativas destinadas a valorizar a diversidade linguística, inclusive voltadas para os povos indígenas, tais como: a criação dos primeiros programas-piloto de educação bilíngue para povos aborígenes, já nos anos 1970; a elaboração de políticas voltadas para o ensino de línguas imigrantes, como a National Policy on Languages, de 1987, que elegia um rol de línguas prioritárias a serem ensinadas; a formulação da Aboriginal Education Policy, com o objetivo de fornecer acesso dos aborígenes à educação, aumentar a frequência escolar e assegurar a participação deles nas políticas educacionais e a criação pelo governo da Aboriginal and Torres Strait Islander Commission, em 1990, com a função de aconselhar o governo no que tange à preservação do patrimônio cultural e linguístico aborígene (LECLERC, 2018).

Contudo, nos últimos anos, constata-se a consolidação de uma política linguística de supremacia do inglês em que escolas indígenas se mostram inexpressivas e línguas imigrantes são ensinadas apenas como disciplinas e restritas ao ambiente familiar. De acordo com o Australian Curriculum, para os dez primeiros anos escolares, conhecido como F-10, que vem sendo desenvolvido desde 2010, o sistema educacional deve proporcionar oito áreas de aprendizado, entre elas o inglês e demais línguas; sete capacidades gerais, entre elas o entendimento intercultural; e três prioridades transcurriculares, como a sustentabilidade, a história e cultura dos povos aborígines e dos povos das ilhas do Estreito de Torres e o envolvimento da Austrália com a Ásia e da Ásia com a própria Ásia (AUSTRALIA, 2018).

$\mathrm{Na}$ área de línguas, são oferecidas aulas de alemão, árabe, chinês, coreano, espanhol, francês, grego, hindi, indonésio, italiano, japonês, língua australiana de sinais, turco, vietnamita e língua indígena como segundas línguas (não como línguas de instrução) com $2 \mathrm{~h}$ por semana, mas apenas até os primeiros 10 anos do currículo escolar. Para Leclerc (2018), as línguas são ensinadas com o propósito de integrar os imigrantes e seus filhos ao país, facilitando, assim, a aquisição da língua inglesa para que possam participar da vida pública e, acrescentaríamos, sem se preocupar com a valorização ou a preservação dessas línguas. ${ }^{31}$ Isso pode ser comprovado no próprio F-10 onde se lê sobre o árabe e sua relação com o inglês:

31 Algo semelhante pode ser observado no Canadá, quando tivemos a oportunidade de analisar o funcionamento do discurso do multiculturalismo nesse país (BARBOSA DA SILVA, 2018). 
O árabe é usado como meio para a interação da classe e para demonstrar e modelar a aquisição de novos idiomas. $\mathrm{O}$ inglês pode ser usado para explicar características do idioma e aspectos da cultura. $O$ inglês e $o$ árabe podem ser usados quando os alunos estão se comunicando sobre semelhanças e diferenças entre o árabe e outras linguas e culturas e refletindo sobre como eles falam e se comportam nos contextos de lingua árabe e de lingua inglesa (AUSTRALIA, 2018, tradução e grifo nosso) ${ }^{32}$

Quanto ao segundo grupo, formado pelo país e territórios também com prevalência da colonização de povoamento, mas com baixa diversidade autóctone, tem como maior expoente a Nova Zelândia, país com apenas duas línguas autóctones, o maori e o moriori (nas Ilhas Chatham, quase extinto) e dezenas de línguas imigrantes. Assim como a Austrália, a Nova Zelândia reviu suas políticas de assimilação dos povos indígenas a partir dos anos 1970, após ampla mobilização de grupos maoris, iniciando uma política de valorização da cultura e da língua locais.

Entre as medidas criadas estavam o programa Te Wiki o Te Reo Māori (Semana da Língua Maori), em 1975, com uma série de eventos voltados para o reconhecimento do maori; o movimento Kōhanga Reo (Ninho de língua), que a partir de 1981, criou escolas pré-primárias de imersão para a cultura e língua maoris, depois estatizadas; a criação das Kura Kaupapa Māori a partir de 1985, complementares às anteriores, para o ensino primário e secundário; a adoção, em 1987, da língua maori como oficial da Nova Zelândia (NASCIMENTO; MAIA; WHAN, 2017) e no mesmo ano a criação da Te Taura Whiri $i$ te Reo Māori (Comissão da Língua Maori), com a função de desenvolver políticas de promoção do maori. Todas essas ações tinham como objetivo reconhecer a importância da língua maori e colaborar na retomada da sua transmissão para as futuras gerações, já que como na Austrália, grande parte da população indígena do país tinha se tornado falante de inglês como primeira língua.

O movimento Kōhanga Reo conseguiu certo sucesso ao ampliar o número de falantes e acabou servindo de modelo para outros países e regiões como o Havaí (com o Pūnana Leo, desde 1984) e também o Brasil no caso do ensino do kaingang (NASCIMENTO; MAIA; WHAN, 2017). Atualmente, o país desenvolve um programa que garante a utilização do maori e de línguas imigrantes como o samoano, o tonganês, o maori das Ilhas Cook e o niueano, como língua de instrução em dois níveis: de $51 \%$ a $80 \%$ e de $80 \%$ a $100 \%$ da grade curricular até o ensino secundário em escolas maoris e no ensino primário para imigrantes. Além disso, a Nova Zelândia apresenta iniciativas como a Semana de Línguas, semelhante a Te Wiki o Te Reo Māori, e investe na produção de material didático para atender às línguas imigrantes, sobretudo as

32 No original: Arabic is used as the medium for class interaction and to demonstrate and model new language acquisition. English may be used to explain features of language and aspects of culture. Both English and Arabic may be used when learners are communicating about similarities and differences between Arabic and other languages and cultures and reflecting on how they talk and behave in Arabic-speaking and English-speaking contexts (AUSTRALIA, 2018, grifo nosso). 
polinésias, que sofrem com a escassez de material didático (NEW ZEALAND, 2018a; 2018 b). Entretanto, ainda que os documentos do governo sejam elaborados nas duas línguas oficiais e que as ruas do país sejam visualmente bilíngues, Leclerc (2018) alerta que o biliguismo na Nova Zelândia está restrito ao povo maori e aos imigrantes porque poucos anglofalantes se interessam em aprender outras línguas.

O terceiro grupo é formado por países e territórios com colonização predominantemente de exploração e baixa diversidade linguística autóctone, sobretudo da Micronésia e da Polinésia, que, como Lynch (1998) afirma, apresentam uma língua por ilha ou grupo de ilhas. De imediato é possível perceber que tais países tendem a implementar uma política de status de tornar oficial a única ou as poucas línguas indígenas ao lado da língua colonizadora europeia. Já no quarto grupo que apresenta países e territórios também com colonização em que predomina a exploração, mas com grande diversidade linguística autóctone, reunindo sobretudo países da Melanésia, é possível observar uma tendência de tornar oficial a língua europeia colonizadora ao lado ou não de línguas crioulas.

Cabe ressaltar que os países e territórios do terceiro grupo poderiam, inclusive, adotar apenas a língua autóctone como oficial devido ao fato de quase toda a população ser falante dessa língua como em Kiribati ou em Tuvalu. ${ }^{33}$ No entanto, tal medida esbarra em diversos problemas, como a falta de recursos para elaboração de materiais didáticos e para a formação de professores ou ainda a pequena população e a sua dispersão por muitas ilhas. Na maioria desses países, inclusive, o ensino superior fica a cargo da University of the South Pacific, com sede em Suva (Fiji), e é realizado a distância, via satélite, mas com polos apenas na capital ou ilha principal e há casos em que sequer existe a oferta de ensino secundário, como em Tokelau e nas Ilhas Pitcairn. Tal situação influencia a migração de jovens para países como a Austrália e Nova Zelândia, que acabam preferindo o ensino em língua inglesa na escola secundária para terem maiores chances profissionais (LEE; FRANCIS, 2009; CONNELL; RAPAPORT, 2013). ${ }^{34}$

Já os países do quarto grupo, além desses problemas, enfrentam uma situação linguística mais complexa. Alguns deles com centenas de línguas locais, têm inclusive que implementar uma política linguística que mantenha a unidade nacional, fazendo com que toda a população possa se comunicar em uma única língua, seja europeia ou crioula, como em Vanuatu ou na Papua-Nova Guiné, que optaram por tornar oficiais línguas crioulas ao lado de línguas europeias. Em outros, entretanto, cabe registrar que ainda se observa certo preconceito com essas línguas crioulas, como nas Ilhas Salomão, que não tornaram o pijin a sua língua oficial ou mesmo no Havaí (território do terceiro grupo) em que apenas recentemente, em 2016, acrescentou em seu censo linguístico a

33 Nesses países, de acordo com a Unesco (2010) e o Ethnologue (2017), as línguas estão menos ameaçadas que na Melanésia, provavelmente por terem Estados responsáveis por suas políticas como Samoa, Tonga e Tuvalu.

34 Dados dos censos nacionais mostram que, atualmente, na Nova Zelândia (2013) vivem cerca de 144 mil samoanos, 61 mil cookianos, 60 mil tonganeses, 23 mil niueanos (quinze vezes a população do território), 14 mil fijianos e 7 mil tokelauanos (cinco vezes a população do território) e na Austrália (2016), 61 mil residentes nasceram em Fiji, 24 mil em Samoa e 10 mil em Tonga. 
opção de resposta para a língua crioula ou ainda nas províncias indonésias de Papua e Papua Ocidental que ainda não registram no censo nacional essa opção.

Quanto às línguas utilizadas na educação, de forma geral nesses dois grupos, podemos observar que a maioria dos países e territórios, entre eles Kiribati, Papua-Nova Guiné, Niue e Samoa, utilizam um bilinguismo de transição. Nesses lugares, a criança é alfabetizada e tem como língua de instrução das séries iniciais a sua primeira língua para depois ser introduzida à língua oficial colonizadora europeia. Muitas vezes seguese a seguinte fórmula, com maior ou menor ênfase na língua materna: língua materna como língua de instrução + língua alóctone como disciplina $=>$ língua materna como língua de instrução e língua alóctone como língua de instrução $=>$ língua alóctone como língua de instrução + língua materna como disciplina. De maneira geral, tal medida teria como vantagem facilitar a aquisição da língua colonizadora, ampliando, consequentemente, a inserção internacional do país no mundo, mas acaba impedindo que as línguas locais alcancem as séries superiores do sistema educacional, restringindo-as aos ambientes familiar e religioso.

Contudo, cabe mencionar certa variedade ou especificidades de métodos no ensino bilíngue do continente. Aqueles países e territórios que não adotam o sistema de biliguismo de transição oferecem disciplinas para o ensino de línguas locais nas séries iniciais, por exemplo, como na Polinésia Francesa (de $2 \mathrm{~h}$ a $2 \mathrm{~h}: 30$ por semana) ou em Fiji (3h a 4 h por semana). Para contornar as dificuldades apresentadas, outros implantam políticas e ações de forma territorializada, como na Micronésia, que oferece a língua local de acordo com regiões do país; de forma segmentada, como em Tonga, onde na capital se encontra maior oferta de escolas com ensino primário em inglês em relação aos locais mais afastados do país por conta do interesse dos pais; ou ainda políticas de caráter étnico, como no Havaí, que oferece instrução na língua havaiana para os descendentes de havaianos; ou por disciplinas como nas Ilhas Marshall, que oferecem disciplinas de estudos sociais, saúde e arte em marshallês e de matemática e ciências em inglês. Já em Palau, a educação bilíngue varia de acordo com a língua materna do professor, e nas Ilhas Marianas do Norte a ausência de recursos para a realização do ensino bilíngue fez com que o governo, a partir de 2004, exigisse proficiência em chamorro ou caroliniano para a conclusão do ensino médio (LECLERC, 2018).

Todavia, mesmo com tantas dificuldades, hão de se destacar alguns avanços voltados sobretudo para a política de corpus — antes mesmo da independência de alguns países, mas especialmente após - , que visam equipar as línguas para assumir espaços e funções de maior importância. Tais avanços poderiam, inclusive, servir de modelo para línguas indígenas brasileiras com maior número de falantes, como o tikuna, o guarani kaiowá, o kaingang, o xavante e o yanomami. Entre essas iniciativas estão a fundação da Kumision I Fino' Chamorro/Comissão da Língua Chamorro (1964), em Guam; a instituição do Kiribati Language Board (1970), em Kiribati; a criação dos programas Pacific Languages Development Project (1970), Bilingual Education Teacher Training (1974) e seus sucessores pela University of Hawai' $i$; a formação da Académie tahitienne (1974), na Polinésia Francesa; e do Institute of Fijian 
Language and Culture (1986), em Fiji; a criação da Chamorro/Carolinian Language Policy Commission (1994), nas Ilhas Marianas do Norte; a constituição da Faleula o fatuaiupu o le gagana samoa/Comissão Internacional da Língua Samoa (2000), em Samoa e em Samoa Americana; e da Te Kopapa Reo Māori/Comissão da Língua Maori (2003), nas Ilhas Cook; a instituição da Customary Law and Language Commission (2004), nas Ilhas Marshall; da Académie de langues kanak (2007), na Nova Caledônia; e a constituição da Niue Language Commission, em Niue. Essas iniciativas criaram órgãos específicos dos governos e programas de universidades responsáveis em maior ou menor grau por elaborar e publicar dicionários bilíngues; padronizar a ortografia; descrever a gramática; atualizar o léxico; ampliar o número de professores; opinar sobre programas educacionais e elaborar materiais didáticos para as línguas locais, ou seja, realizar as políticas linguísticas de corpus e de aquisição desses países (SPENCER, 1996; LECLERC, 2018).

\section{Considerações finais}

Neste artigo, observamos que o colonialismo modificou o ambiente linguístico dessa região que já era a linguisticamente mais complexa do mundo antes dos europeus chegarem, introduzindo outras línguas bastante distintas com grafias e sentidos outros para além daqueles já conhecidos pelos povos indígenas da Oceania. Se por um lado, constatamos, ao longo da colonização do continente, o extermínio e a transformação de línguas locais por meio da imposição das línguas europeias; por outro, observamos um processo de descolonização linguística a partir dos anos $1970 \mathrm{em}$ que se produz outra memória sobre as línguas colonizadas e também sobre as línguas colonizadoras, marcadas nas muitas línguas crioulas de base europeia ou ainda no inglês neozelandês e australiano que Holm (2000) inclusive classifica como semi-crioulo.

Tal situação fez com que os povos da Oceania se tornassem povos de fronteiras fronteiras de línguas, fronteiras de sentidos, fronteiras de memórias sejam elas entre as línguas colonizadoras, as autóctones e as imigrantes. Não fronteiras rígidas, mas porosas, multilíngues, com muitas trocas e movimentos, com sentidos que vão e vêm e que afetam não apenas as línguas locais, mas também as línguas europeias, ainda que estejam restritas a espaços de uso da Igreja ou do Estado, respectivamente.

Ainda assim, há de se destacar que, apesar da escassez dos mais variados recursos, os países e territórios da região apresentam uma relevante política linguística de status, de corpus e de aquisição, garantindo o reconhecimento de línguas locais pelo Estado; fomentando alterações linguísticas gramaticais e lexicais para que possam ocupar outros espaços e ampliando a aquisição de habilidades escritas da população nessas línguas. Tais iniciativas são, assim, fundamentais para que se possa, se não reverter o desaparecimento de línguas, pelo menos reduzi-lo preservando de forma sustentável esse complexo e vivo ambiente linguístico. 
BARBOSA DA SILVA, D. Language policy in Oceania: in the frontiers of colonization and globalization. Alfa, São Paulo, v. 63, n.2, p.317-347, 2019.

- ABSTRACT: In this article, we present an overview of the language policies adopted in the Oceanian countries and territories after analysis of legislation, plans and government programs. Representing $22.9 \%$ of all languages in the world - the vast majority spoken by few people and endangered -, this continent suffered an intense linguistic colonization marked by the instrumentalisation of indigenous languages by missionaries and by the subsequent imposition of European languages as the only ones allowed during European and American imperialism. Such a scenario has broadened the complex linguistic situation in Oceania and has imposed on the countries of the region many challenges about languages to adopt after their independences, in view of the many local problems, which caused the Oceanian peoples to seek diverse political solutions and to become frontier peoples - frontiers of languages, frontiers of meanings, frontiers of memories, frontiers between colonizer languages, indigenous languages and immigrant languages.

- KEYWORDS: Language policy. Oceania. Linguistic colonization. Bilingualism. Languages in contact.

\section{REFERÊNCIAS}

AUSTRÁLIA. Australian Bureau of Statistics. Language spoken at home. 2016. Disponível em: https://profile.id.com.au/australia/language. Acesso em: 24 ago. 2019.

AUSTRÁLIA. Australian Curriculum. Assessment and Reporting Authority (ACARA). Understand how F-10 curriculum works. 2018. Disponível em: https://www. australiancurriculum.edu.au/f-10-curriculum/. Acesso em: 26 ago. 2019.

AUSTRÁLIA. Convict transportation registers database. 2008. Disponível em: http://blogs.slq.qld.gov.au/jol/2008/08/20/convict-transportation-registers-database/. Acesso em: 05 set. 2019.

BARBOSA DA SILVA, D. Uma terra hospitaleira de muitos imigrantes vindos do mundo todo: a emergência do discurso do multiculturalismo no Canadá. Interfaces Brasil/Canadá, Florianópolis; Pelotas; São Paulo, v. 18, n. 1, 2018. Disponível em: http://dx.doi.org/10.15210/interfaces.v18i1.13087. Acesso em: 29 ago. 2019.

BARBOSA DA SILVA, D. Política lingüística en África: del pasado colonial al futuro global. Estudios de Asia y África, Ciudad de Mexico, v. 46, n. 1, p.65-95, 2011. Disponível em: https://www.researchgate.net/publication/261737711_Politica Linguistica_en_Africa_del_pasado_colonial_al_futuro_global. Acesso em: 29 ago. 2019. 
CALVET, L.-J. As políticas linguísticas. São Paulo: Parábola, 2007. Obra original de 1995 .

CALVET, L.-J. Sociolinguística. São Paulo: Parábola, 2002. Obra original de 1993.

CAMPBELL, I. C. Island Kingdom: Tonga ancient and modern. Christchurch: University of Canterbury, 2015. Obra original de 1992.

CAMPBELL, I. C. Worlds Apart: a history of the Pacific Islands. Christchurch: Canterbury University Press, 2003. Obra original de 1989.

CHAPPELL, D. The Postcontact Period. In: RAPAPORT, M. The Pacific Islands. Honolulu: University of Hawaii Press, 2013a. p.138-146.

CHAPPELL, D. The Kanak Awakening: The Rise of Nationalism in New Caledonia. Honolulu: University of Hawaii Press, 2013b.

COCHRANE, E. E.; HUNT, T. L. (ed.). The Handbook of Prehistoric Oceania. New York: Oxford University Press, 2018.

CONNELL, J.; RAPAPORT, M. Mobility to migration. In: RAPAPORT, M. The Pacific Islands. Honolulu: University of Hawaii Press, 2013. p.275-286.

COOPER, R. L. La planificación linguística y el cambio social. Cambridge: Cambridge University Press, 1997. Obra original de 1989.

CORLEW, L. K. The cultural impacts of climate change: sense of place and sense of community in Tuvalu, a country threatened by sea level rise. Scotts Valley, CA: CreateSpace Independent Publishing Platform, 2012.

COUTO, H. H. do. Introdução ao estudo das línguas crioulas e pidgins. Brasília: UnB, 1996.

DENOON, D. (ed.). The Cambridge History of the Pacific Islanders. Cambridge: Cambridge University Press, 1997.

DRAGER, K. Pidgin and Hawaii English: an overview. International Journal of Language, Translation and Intercultural Communication, Igoumenitsa, v.1, n.1, p. 61-73, 2012. Disponível em: <https://ejournals.epublishing.ekt.gr/index.php/latic/ article/viewFile/2717/2485>. Acesso em: 23 ago. 2019.

ETHNOLOGUE. Languages of the World. 2017. Disponível em: https://www. ethnologue.com. Acesso em: 20 mar. 2018.

FERRO, M. História das colonizações: das conquistas às independências. São Paulo: Companhia das Letras, 1996. Obra original de 1994.

FIRTH, S. Colonial Administration and the Invention of the Native. In: DENOON, D. (ed.). The Cambridge History of the Pacific Islanders. Cambridge: Cambridge University Press, 1997. p.253-288. 
FISCHER, S. R. A History of the Pacific Islands. London: Palgrave Macmillan, 2013. Obra original de 2002.

FOERSTER, R.; PAKARATI, C. More Manava. Rapa Nui: Rapa Nui Press, 2016. FRY, G.; TARTE, S. The New Pacific Diplomacy. Canberra: Australian National University Press, 2016.

GOTT, R. El imperio británico. Buenos Aires: Capital Intelectual, 2013. Obra original de 2011 .

GRAIG, R. D. Historical Dictionary of Polynesia. Plymouth: The Scarecrow Press, 2011.

HAMEL, R. La globalización de las lenguas em el siglo XXI entre la hegemonía del inglés y la diversidad linguística. In: HORA, D. da; LUCENA, R. (org.). Política linguística na América Latina. João Pessoa: Ideia: Editora Universitária, 2008. p. $45-78$.

HAVAÍ. Department of Business, Economic Development \& Tourism. Detailed Languages Spoken at Home in the State of Hawaii, 2016. Disponível em: http:// files.hawaii.gov/dbedt/census/acs/Report/Detailed_Language_March2016.pdf. Acesso em: 23 ago. 2019.

HOBSBAWM, E. A Era dos Impérios (1875-1914). São Paulo: Paz e Terra, 2011. Obra original de 1988.

HOLM, J. An introduction to pidgins and creoles. Cambridge: Cambridge University Press, 2000.

HORNE, G. The white Pacific. Honolulu: University of Hawaii Press, 2007.

HOUAISS. Dicionário Houaiss da Língua Portuguesa. Rio de Janeiro: Objetiva, 2001.

KING, M. The Penguin History of New Zealand. Auckland: Penguin Books, 2003.

KIRCH, P. V. On the road of the winds: an archaeological history of the Pacific Islands before European contact. Los Angeles: University of California Press, 2000.

KLOSS, H. Research possibilities on group bilingualism: a report. Quebec: CIRB, 1969.

KLUGE, A. J. H. A grammar of Papuan Malay. 2014. Thesis (Doctor in Linguistic) Faculteit Geesteswetenschappen, Universiteit Leiden, Leiden, 2014.

LAL, B. V.; FORTUNE, K. (ed.). The Pacific Islands: an encyclopedia. Honolulu: University of Hawaii Press, 2000.

LECLERC, J. L'aménagement linguistique dans le monde. 2018. Disponível em: http://www.tlfq.ulaval.ca/axl/. Acesso em: 15 mar. 2018. 
LEE, H.; FRANCIS, S. T. Migration and Transnationalism: Pacific perspectives. Canberra: The Australian National University, 2009.

LYNCH, J. Multilingualism: language diversity. In: SATO, H.; BRADSHAW, J. (ed.). Languages of the Pacific Islands. Scotts Valley, CA: CreateSpace Independent Publishing Platform, 2017. p.63-71.

LYNCH, J. Pacifics languages: an introduction. Honolulu: University of Hawaii Press, 1998.

MACINTYRE, S. A concise history of Australia. Cambridge: Cambridge University Press, 2009.

MACLELLAN, N. Pacific Diplomacy and Decolonisation in the $21^{\text {st }}$ Century. In: FRY, G.; TARTE, S. The New Pacific Diplomacy. Canberra: Australian National University Press, 2016. p.263-284.

MARIANI, B. Colonização Linguística. Campinas: Pontes, 2004.

McINTYRE, W. D. Winding up the British Empire in the Pacific Islands. Oxford: Oxford University Press, 2014.

MUGLER, F.; LYNCH, J. Language and education in the Pacific. In: MUGLER, F.; LYNCH, J. (ed.). Pacific Languages in Education. Suva: University of South Pacific, 1996. p.1-9.

MÜHLHÄUSLER, P. Linguistic Ecology: Language chance and linguistic imperialism in the Pacific region. London: Routledge, 1996.

NASCIMENTO, M.; MAIA, M.; WHAN, C. Kanhgág vĩ jagfe: ninho de língua e cultura kaingang na terra indígena Nonoai (RS): uma proposta de diálogo intercultural com o povo Māori da Nova Zelândia. Revista LinguíStica, Rio de Janeiro, v.13, n.1, p. 367-383, jan. 2017.

NOVA ZELÂNDIA. New Zealand's Constitution. 2013 Census QuickStats about culture and identity. Disponível em: http://archive.stats.govt.nz/Census/2013-census/ profile-and-summary-reports/quickstats-culture-identity.aspx. Acesso em: 23 abr. 2018.

NOVA ZELÂNDIA. Education Counts. Māori Language in Education. 2018a. Disponível em: https://www.educationcounts.govt.nz/statistics/maori-education/maoriin-schooling/6040. Acesso em: 30 abr. 2018.

NOVA ZELÂNDIA. Ministry for Pacific Peoples. Pacific Language Weeks. 2018b. Disponível em: http://www.mpp.govt.nz/language-culture-and-identity/. Acesso em: 30 abr. 2018.

ORLANDI, E. Terra à vista: Discurso do confronto: Velho e Novo Mundo. Campinas: Ed. da Unicamp, 2008. Obra original de 1990. 
OUANE, A. (org.). Towards a multilingual culture of education. Hamburg: Unesco Institute for Education, 2003.

PAWLEY, A. Language. In: RAPAPORT, M. The Pacific Islands. Honolulu: University of Hawaii Press, 2013. p.159-171.

QUANCHI, M.; ROBSON, J. The A to $\mathbf{Z}$ of the Discovery and Exploration of the Pacific Islands. Lanham: The Scarecrow Press, 2009.

SCARR, D. The History of the Pacific Islands: Kingdoms of the Reefs. South Melbourne: Macmillan Company, 1990.

SKIRGÅRD, H.; CARTOGIS. Map of Subregions of Oceania. College of Asia-Pacific at the Australian National University, 2019. Disponível em: https://sites.google.com/ site/hedvigskirgard/pacific-maps. Acesso em: 05 set. 2019.

SNIJDERS, J. A mission too far...: Pacific Commitment (1835-1841). Adelaide: ATF, 2012.

SPENCER, M. And what of the languages of Micronesia? In: MUGLER, F.; LYNCH, J. (ed.). Pacific Languages in Education. Suva: University of South Pacific, 1996. p.10-35.

UNESCO. Organização das Nações Unidas para a Educação, a Ciência e a Cultura. Atlas of the World's Languages in Danger. Paris: Unesco, 2010.

UNITED NATIONS POPULATION FUND [UNFPA] State of World Population 2010: From Conflict and Crisis to Renewal: Generations of Change. Disponível em: http://www.unfpa.org/swp/2010/web/es/pdf/ES_SOWP10_DemSocialEcon.pdf. Acesso em: 19 ago. 2019.

United states GeOlogicAl SURVEY [USGS]. Mineral Commodity Summaries, 2011. Disponível em: http://minerals.usgs.gov/minerals/pubs/commodity/ nickel/mcs-2011-nicke.pdf. Acesso em: 04 ago. 2019.

\section{BIBLIOGRAFIA CONSULTADA}

AUSTRÁLIA. Parliament of Australia. The Australia Constitution. Disponível em: https://www.aph.gov.au/About_Parliament/Senate/Powers_practice_n_procedures/ Constitution. Acesso em: 05 set. 2019.

DEVERELL, G. Towards the formulation of a language policy for Pacific Preschools: a survey of language use by parents and teachers. Directions: Journal of Educational Studies, Suva, v.8, n.16, 1986, p. 73-86. 
EARLY, R. A survey of educational language policies in the Pacific region. In: INTERNATIONAL CONFERENCE ON LANGUAGE AND EDUCATION, 5., 2016, Bangkok. Sustainable Development Through Multilingual Education, Bangkok, Oct. 2016. Disponível em: http://www.lc.mahidol.ac.th/mleconf/2016/Documents/ PresentedFiles/Parallel\%20V/T1-7/12A-Robert_Early.pdf. Acesso em: 23 ago. 2019.

FIJI. Parliament of Fiji Islands. Constitutions of Fiji Islands. Disponível em: http:// www.paclii.org/fj/Fiji-Constitution-English-2013.pdf. Acesso em: 20 abr. 2018.

FIJI. Fiji Islands Bureau of Statistics. 2017 Census. Disponível em: https://www. statsfiji.gov.fj/index.php/census-2017. Acesso em: 03 mai. 2018.

GABILLON, Z.; AILINCAI, R. Multilingual primary education initiative in French Polynesia. Procedia: Social and Behavioral Sciences, Amsterdam, v. 174, p.3595-3602, 2015. Disponível em: https:/halshs.archives-ouvertes.fr/halshs-01137595/document. Acesso: 23 ago. 2019.

GUAM. Government of Guam's Statistical Information. Guam 2010 Census Demographic Profile. Disponível em: https://sdd.spc.int/media/306. Acesso em: 05 set. 2019.

HAVAÍ. Hawaii State Department of Education. Disponível em: http://www. hawaiipublicschools.org/. Acesso em: 15 abr. 2018.

ILHAS COOK. Cook Islands Statistics Office. Census 2016. Disponível em: http:// www.mfem.gov.ck/statistics/census-and-surveys/census/142-census-2016. Acesso em: 05 set. 2019.

ILHAS MARIANAS DO NORTE. Department of Commerce. Disponível em: http:// commerce.gov.mp/. Acesso em: 05 set. 2019.

ILHAS MARIANAS DO NORTE. Department of Accountability, Research \& Evaluation. Disponível em: https://www.cnmipssoare.org/. Acesso em: 05 set. 2019.

ILHAS MARSHALL. Nitijela: The Parliament of the Republic of the Marshall Islands. Constitution of the Republic of the Marshall Islands. Disponível em: https:// rmiparliament.org/cms/constitution.html. Acesso em: 05 set. 2019.

ILHAS MARSHALL. Economic Policy, Planning and Statistics Office. RMI Census 2011. Disponível: https://www.rmieppso.org/social/census-report. Acesso: 05 set. 2019.

ILHAS SALOMÃO. Parliament of Solomon Islands. Constitution of Solomon Islands. Disponível em: http://www.parliament.gov.sb/files/business\&procedure/constitution. htm. Acesso em: 20 mai. 2019.

ILHAS SALOMÃO. Solomon Islands National Statistics Office. Census 2009. Disponível em: https://www.statistics.gov.sb/statistics/demographic-statistics/census. Acesso em: 05 set. 2019. 
INDONÉSIA. Badan Pusat Statistik. Kewarganegaraan, Suku Bangsa, agama, dan Bahasa Sehari-hari Penduduk Indonesia: hasil sensus penduruk 2010. 2011. Disponível em: https:/www.bps.go.id/publication/2012/05/23/55eca38b7fe083083 4605b35/kewarganegaraan-suku-bangsa-agama-dan-bahasa-sehari-hari-pendudukindonesia.htm. Acesso: 24 abr. 2019.

KEPHAS, J. Prospects for the future: The case of Nauru. Directions: Journal of Educational Studies, Suva, v.27, n.1, p. 107-112, 2005. Disponível em: http://www. directions.usp.ac.fj/collect/direct/index/assoc/D1175081.dir/doc.pdf. Acesso em: 20 ago. 2019.

KIRIBATI. The Constitution of Kiribati. Disponível em: https://www.policinglaw. info/assets/downloads/1979_Constitution_of_Kiribati.pdf. Acesso em: 05 set. 2019.

KIRIBATI. Kiribati National Statistics Office. 2005 Census of Population. Disponível em: http://www.mfed.gov.ki/sites/default/files/Census-Report-2005-Volume-1-FinalReport_0.pdf. Acesso em: 05 set. 2019.

KIEVIET, P. A grammar of Rapa Nui. Berlin: Language Science Press, 2017.

MICRONÉSIA. The Constitution of the Federated States of Micronesia. Disponível em: http://www.fsmlaw.org/fsm/constitution/constitution.htm. Acesso em: 20 mai. 2015.

MICRONÉSIA. Federated States of Micronesia Division of Statistics. Population Statistics. Disponível em: http://www.fsmstatistics.fm/?page_id=254. Acesso em: 05 set. 2019.

MÜHLHÄUSLER, P. From despised jargon to language of education Recent developments in the teaching of Norf'k. In: VOLKER, C. A. (ed.). Education in Languages of Lesser Power: Asia-Pacific Perspectives. Amsterdam: John Benjamins Publishing, 2015.

NAURU. Parliament of Nauru. The Constitution of Nauru. Disponível em: http:// www.naurugov.nr/parliament/constitution.html. Acesso em: 05 set. 2019.

NAURU. Nauru Bureau of Statistics. 2011 Census. Disponível em: https://nauru.prism. spc.int/nauru-documents. Acesso em: 05 set. 2019.

NIUE. Niue Statistics. Disponível em: http://niue.prism.spc.int/. Acesso em: 05 set. 2019.

NOVA CALEDÔNIA. Institut de La Statistique Eet des Études Économiques. Disponível em: http://www.isee.nc/. Acesso em: 03 jan. 2015.

NOVA ZELÂNDIA. Tau Mai Te Reo. The Mäori Language in Education Strategy 2013 - 2017. Disponível em: https:/education.govt.nz/assets/Documents/Ministry/ Strategies-and-policies/TauMaiTeReoFullStrategy-English.pdf. Acesso em: 05 mai. 2018. 
PALAU. Palau Constitution. Disponível em: https://www.palaugov.pw/about-palau/ constitution/. Acesso em: 05 set. 2019.

PALAU. Bureau of Budget and Planning: Office of Planning and Statistics. 2005 Census. Disponível em: https://www.palaugov.pw/wp-content/uploads/2013/07/ DetailedPOP_tabs.pdf. Acesso em: 05 set. 2019.

PAPUA-NOVA GUINÉ. National Parliament of Papua New Guinea. Constitution of The Independent State of Papua New Guinea. Disponível em: http://www.parliament. gov.pg/constitution-of-the-independent-state-of-papua-new-guinea. Acesso em: 05 set. 2019.

PAPUA-NOVA GUINÉ. National Statistical Office of Papua New Guinea. 2011 Census. Disponível em: https://www.nso.gov.pg/. Acesso em: 05 set. 2019.

PENE, F.; MUGLER, F. The language context of pacific countries: a summary. Directions: Journal of Educational Studies, Suva, v.27, n.1, p.134-143, 2005.

SALLABANK, J. Language ideologies, practices and policies in Kanaky/New Caledonia. In: JONES, M. (ed.). Language Policy for Endangered Languages. Cambridge: Cambridge University Press, 2015.

SAMOA. Parliament of Samoa. The Constitution of the Independent State of Samoa. Disponível em: http:/www.palemene.ws/new/wp-content/uploads/Document/2016Constitution-of-Samoa-Eng.pdf. Acesso em: 05 set. 2019.

SAMOA. Samoa Bureau of Statistics. 2011 Census. Disponível em: http:/www.sbs. gov.ws/library/populationanddemography. Acesso em: 05 set. 2019.

SAMOA AMERICANA. Department of Commerce. American Samoa Statistical Yearbook 2011. Disponível em: http://doc.as.gov/research-and-statistics/statisticalyearbook/. Acesso em: 17 abr. 2018.

TOKELAU. Tokelau National Statistics Office. 2016 Tokelau Census. Disponível em: https:/www.tokelau.org.nz/Tokelau+Government/Government+Departments/Office+ of + the + Council + for + the + Ongoing + Government + OCOG/Tokelau + National + Statistic s+Office/census.html. Acesso em: 05 set. 2019.

TONGA. Act of Constitutions of Tonga. Disponível em: https://www.parliament.gov. to/parliamentary-business/documents/constitution-of-tonga/file/115-constitution-oftonga-revised-1988. Acesso em: 05 set. 2019.

TONGA. Tonga Department os Statistics. Census 2006. Disponível em: https://tonga. prism.spc.int/census-population\#reports. Acesso em: 05 set. 2019.

TUVALU. The Constitution of Tuvalu. Disponível em: http:/www.tuvaluislands. com/const_tuvalu.htm. Acesso em: 05 set. 2019. 
TUVALU. Tuvalu Central Statistics Division. Census 2017. Disponível em: https:// tuvalu.prism.spc.int/index.php/tuvalu-documents. Acesso em: 05 set. 2019.

VANUATU. Constitution of the Republic of Vanuatu. Disponível em: http://www. paclii.org/vu/legis/consol_act/cotrov406/. Acesso em: 05 set. 2019.

VANUATU. Vanuatu National Statistics Office. 2009 National Population and Housing Census. Disponível em: https:/vnso.gov.vu/index.php/census-and-surveys/ census/censuses. Acesso em: 05 set. 2019.

WALLIS E FUTUNA. Service Territorial de La Statistique et des Études Économiques. Recensement 2008. Disponível em: http://www.statistique.wf/recensements-etenquetes/recensement-general-de-la-population/. Acesso em: 05 set. 2019.

WILSON, W. H. Hawaiian language revitalization. In: SATO, H.; BRADSHAW, J. (ed.). Languages of the Pacific Islands. Scotts Valley, CA: CreateSpace Independent Publishing Platform, 2017.

Recebido em 15 de maio de 2018

Aprovado em 28 de janeiro de 2019 